
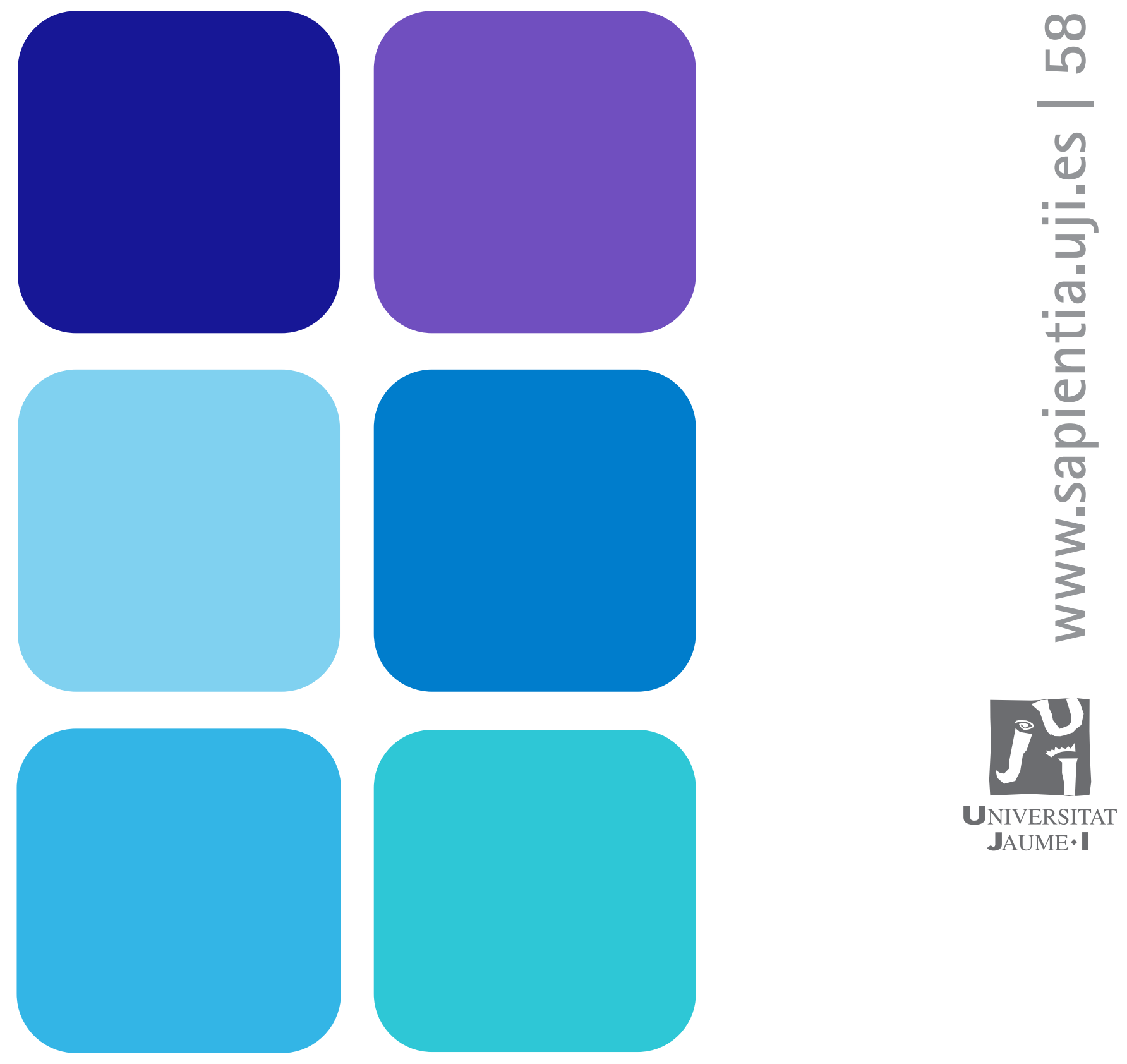

\title{
Com traduir del francès
}

Joan Verdegal 


\section{Com traduir del francès}

Joan Verdegal

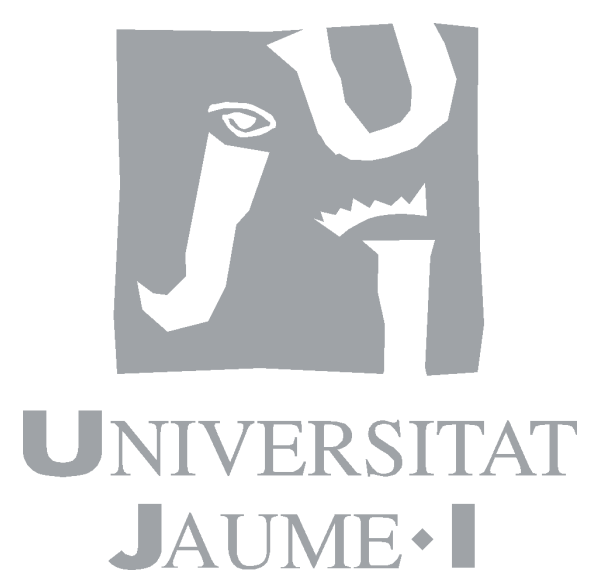

Departament de Traducció I Comunicació

Codi d'assignatura TI0937 
Edita: Publicacions de la Universitat Jaume I. Servei de Comunicació i Publicacions Campus del Riu Sec. Edifici Rectorat i Serveis Centrals. 12071 Castelló de la Plana http://www.tenda.uji.esｅ-mail: publicacions@uji.es

Col·lecció Sapientia, 58

Primera edició, 2011

www.sapientia.uji.es

ISBN: 978-84-694-2872-6

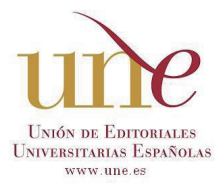

Publicacions de la Universitat Jaume I és una editorial membre de l'UNE, cosa que en garanteix la difusió de les obres en els àmbits nacional i internacional.

\section{(c) (i) (9)(2)}

Aquest text està subjecte a una llicència Reconeixement-NoComercial-Compartirlgual de Creative Commons, que permet copiar, distribuir i comunicar públicament l'obra sempre que especifique l'autor i el nom de la publicació i sense objectius comercials, i també permet crear obres derivades, sempre que siguen distribuïdes amb aquesta mateixa llicència.

http://creativecommons.org/licenses/by-nc-sa/2.5/es/deed.ca 


\section{ÍNDEX}

Pròleg

\section{Capítol I.}

Les normes del sistema lingüístic en traducció francès-català

1.1. La reordenació de les frases

1.2. Els articles

1.3. El substantiu

1.4. L'adjectiu qualificatiu.

1.5. La possessió

1.6. Els determinants i pronoms demostratius

1.7. Els determinants i pronoms indefinits

1.8. Els pronoms personals .

1.9. Els pronoms relatius

1.10. Els determinants i pronoms interrogatius

1.11. Els verbs i les perífrasis verbals

1.12. Els adverbis i locucions adverbials

1.13. Algunes proposicions independents

1.14. Les preposicions

1.15. Les conjuncions

1.16. Les oracions subordinades relatives

1.17. Les oracions subordinades temporals

1.18. Les oracions subordinades condicionals

1.19. La causa i la conseqüència

1.20. La concessió

1.21. La comparació

1.22. Les abreviatures, les sigles i els acrònims

\section{Capítol II.}

Selecció de textos per a traduir en francès-català

2.1. L'extracció de nocions clau

2.2. La captació de les pressuposicions

2.3. La superació de les estructures

2.4. Els neologismes

2.5. L'estil

2.6. El grau d'implicació

2.7. Els argots

2.8. Les oposicions i els contrastos

2.9. L'organització textual 
2.10. L'argumentació

2.11. Les ambigüitats

2.12. Els sobreentesos

2.13. La modulació de les repeticions

2.14. La precisió lèxica

2.15. La denotació i la connotació

\section{Capítol III.}

Bibliografia bàsica i fonts de materials

3.1. Bibliografia sobre teoria de la traducció

3.2. Bibliografia sobre didàctica de la traducció

3.3. Altres bibliografies .

3.4. Diccionaris i obres de consulta .

3.5. Fonts de materials

3.6. Pàgines web 


\section{Pròleg}

Aquesta publicació té la finalitat d'aportar materials docents que no es troben de manera exhaustiva en manuals universitaris de traducció. Un dels objectius generals d'una assignatura de traducció francès-català ha de ser necessàriament dominar aspectes contrastius bàsics d'aquesta combinació lingüística. Si bé les assignatures de llengua francesa per a traductors poden incloure implícitament alguns d'aquests elements dins dels objectius gramaticals, els crèdits disponibles de docència no sempre són suficients per a aprenents de traducció. Per això precisament s'ha concebut el primer capítol d'aquest manual, que tracta sobre la traducció de les normes lingüístiques: funcionaments normatius, condicionants semàntics i pragmàtics, comparatisme en el camp de les convencions textuals. Al mateix temps, aquesta publicació s'ha proposat oferir materials docents per a complir els objectius textuals d'una assignatura de traducció francès-català, com són els de saber detectar i resoldre les particularitats de la traducció de textos de diverses tipologies. És el que es presenta al segon capítol, que aporta una selecció de textos curts (traduïbles la majoria en temps real d'una classe), per refermar les convencions de l'escriptura, detectar els elements d'interferència lèxica i assimilar el caràcter textual del dinamisme de l'equivalència traductora. Aquest segon objectiu és fonamental per a l'adquisició de competències traductores bàsiques que faciliten la tasca docent i discent en l'assignatura de traducció francès-català d'un curs més avançat. El tercer capítol recull una bibliografia que es considera bàsica en aquest nivell de traducció, amb les fonts dels materials didàctics emprats.

Aquesta aportació a l'ensenyament de la traducció francès-català naix amb la vocació d'ajudar l'alumnat a sistematitzar conceptes i a desenvolupar una competència traductora que capacite per a traduir amb garantia de qualitat textos de caràcter general, és a dir, no especialitzats. Els materials que s'hi presenten estan calculats per a un primer curs de traducció de cent hores presencials, però no de forma exclusiva, sinó amb la col·laboració d'altres recursos que haurà de subministrar el professorat. Tanmateix, el primer capítol es pot estudiar i assimilar de manera autònoma, ja que tots els exemples disposen d'unes solucions que no necessiten cap context. A l'inrevés, el segon capítol requereix la col·laboració del professorat, que és qui establirà les pautes i els objectius específics que cal abastar per a aconseguir un nivell acceptable de qualitat. No obstant això, els quinze textos han rebut un tractament de presentació divers, atenent a la progressió didàctica: en el primer bloc inicial de cinc textos hi ha notes al peu que alerten explícitament de certes dificultats que cal superar; en el segon bloc -també de cinc textos- s'ha optat per subratllar simplement aquells aspectes que cal tenir més en compte; finalment, el tercer bloc manca de qualsevol anotació o marca, a fi de poder observar el grau de consecució de la competència traductora i d'avaluar-la mitjançant una correcció objectiva.

Deixem, doncs, a la vista, les pàgines virtuals d'aquest llibre, amb la confiança que serà útil per a les classes universitàries de traducció francès-català.

Joan Verdegal

Universitat Jaume I 


\section{Capítol I. \\ Les normes del sistema lingüístic en traducció francès-català}

Si s'entén la traducció com la restitució en el text meta (TM) del contingut semàntic del text original (TO), el paper de les estructures gramaticals serà important en la mesura que vehiculen elements semàntics i pragmàtics. En aquest sentit, H. Chuquet i M. Paillard (1987: 33) afirmen: «tout décalage grammatical entre les deux langues est une modulation, un changement de point de vue plus systématique et contraignant dans ce cas».

A partir, doncs, de correspondències de contingut més que de correspondències formals, les traduccions de les normes gramaticals d'una llengua hauran de ser assimilades en les primeres fases del procés d'aprenentatge de la disciplina, de manera que caldrà tenir a l'abast una bona gramàtica francesa per a consultes de cert calat (per exemple: Le bon usage, de M. Grevisse), o un bon manual de referència per a qüestions més generals (per exemple: Repères grammaticaux fondamentaux en français, de N. Dulin i S. Palafox). A vegades, els canvis en l'estructura gramatical es deuen a funcionaments normatius diferents, i en altres casos es deuen a condicionants semàntics i pragmàtics. Ch. Nord (1991: 159) adverteix de la importància i de la utilitat de recórrer a la gramàtica contrastiva per a la resolució d'aquest tipus de problemes. Encara que no és un objectiu d'aquest apartat oferir un inventari exhaustiu de totes les diferències i problemes existents entre les llengües francesa i catalana, sí que és convenient brindar un espai per a aqueix tipus d'exercicis de traducció. Sense pretendre simplificar aquests problemes i reduir-los a categories fixes o a criteris estàtics, resulta pertinent aplicar-hi normes comunicatives que puguen delimitar en certa manera (comunicativament) les opcions del traductor, tot servint de «filtres» que en restringeixen l'arbitrarietat i hi estableixen límits. D’altra banda, ningú no posa en dubte la necessitat de les aportacions comparatistes en el camp de les convencions textuals a l'hora d'ensenyar a produir textos convencionals (Lvóvskaya, 1997: 99, 125).

\subsection{La reordenació de les frases}

L'ordre de les paraules en les frases, i de les frases entre si, queda establert, normalment, per causes històriques i d'ús, de tal manera que, si bé en alguns casos hi ha possibilitat de combinacions diferents per a dir les mateixes coses, en d'altres, els elements discursius solen seguir unes pautes prou repetitives. Entre el francès i el català cal tenir presents algunes reordenacions molt habituals (Tricás, 1995: 170-173), que delaten amb massa freqüència traduccions precipitades o gens professionals, sobretot en la premsa escrita: 
- Segments temporals, espacials o modals intercalats en el text de la llengua original (LO) que ocuparan normalment en llengua meta (LM) el començament de la frase:

Le public, admis exceptionnellement sur ces quais, pourra vibrer aux chants des matelots.

De manera excepcional, el públic ha pogut accedir als molls, on podrà vibrar amb les cançons dels mariners.

- Reordenació del grup substantiu + grup adjectiu. És el cas en què el francès prefereix anteposar un grup adjectiu a un substantiu:

Présent au grand rassemblement des voiliers de Brest, le Juan Sebastian Elcano a fait les délices du nombreux public.

El Juan Sebastián Elcano, que estava present a la gran parada de velers de Brest, va fer les delícies d'un públic nombrós.

- Reordenació del grup sintagma nominal + complement preposicional. El francès sol situar en primer lloc el segment preposicional i després el nucli substantiu; el català prefereix, però, posposar el complement:

Par ce soutien inadmissible, le préfet a pris la décision de le mettre à la porte.

El prefecte va prendre la decisió de fer-lo fora a causa d'aquell suport inadmissible.

En el cas de les presentacions de personatges, el francès sol anteposar les descripcions a la identitat; ocorre el contrari en català:

Les épaules larges, une barbe noire et un visage pensif, M. Rigal parlait lentement d'une voix chaude de méridional.

El senyor Rigal, de muscles amples, barba negra i visatge pensívol, parlava lentament, amb càlida veu de meridional.

En definitiva, les reordenacions són múltiples i variades, i s'expliquen en molts casos per raons d'índole rítmica (però també per l'estructura de la frase traduïda):

C'était assez épuisant pourtant, de penser à autre chose.

Tanmateix, resultava prou esgotador pensar en una altra cosa.

\subsection{Els articles}

Els articles indefinits del plural (o la preposició «de» que els substitueix en les frases negatives) s'empren amb més freqüència en francès que en català, i no sempre han de traduir-se:

Chez moi, j'ai des livres.

A casa tinc llibres.

Le jardin donne de beaux fruits.

L'hort dóna belles fruites.
Vous n'avez pas d'amis?

Vostè no té amics? 
Els articles definits presenten una certa varietat de dificultats:

- No s'empren en francès davant dels dies de la setmana, excepte per a indicar la periodicitat (en singular en francès; en plural o en singular en català); tampoc no s'usen (en francès ni en català) per a indicar el dia immediatament pròxim:

J'irai chez toi lundi prochain.

Aniré a ta casa el proper dilluns.

D'accord. À mardi à dix heures.

D'acord. Fins dimarts a les deu.
Elle ne travaille pas le dimanche.

Els diumenges no treballa.

- Han d'afegir-se en LM en el cas d'expressar les hores:
Vers deux heures.
Il est six heures et demie.
Cap a les dues.
Són les sis i mitja.

- No hi ha article en català davant dels noms de països o regions (el francès fa servir generalment l'article definit), excepte en alguns casos encunyats:
La France et l'Espagne font partie de l'Europe. França i Espanya formen part d'Europa.
C'est Pizarro qui a conquis le Pérou. Fou Pizarro qui conquistà el Perú.
Le Roussillon est encore catalan.
Connaissez-vous la Corse?
El Rosselló encara és català.
Coneixeu Còrsega?

Els articles partitius francesos (o la preposició «de» que els substitueix en negativa) no tenen equivalent en català:
L'homme mange du pain.
Il n'y a pas de craie.
L'home menja pa.
No hi ha guix.

\subsection{El substantiu}

Els complements del nom són introduïts en francès per la preposició «à»; en català podem triar «de»o «amb»:

Une armoire à glace.

Un armari de lluna.
Un bifteck aux pommes.

Un bistec amb pataques.

L'expressió «coup de» es tradueix tant amb «colp de» com amb sufix:

Un coup de poing.

Un colp de puny.

Un coup d'oeil.

Un colp d'ull. / Una ullada.
Un coup de marteau.

Una martellada.

Un coup de mer.

Una onada. / Un colp de mar. 


\title{
1.4. L'adjectiu qualificatiu
}

Hi ha construccions clarament diferents d'alguns adjectius en francès i català. S'atenen a les regles següents:

- Quan l'adjectiu es refereix a un substantiu, à + infinitif $>$ de + infinitiu

C'est facile/difficile à résoudre.

Ce froid est dur à supporter.

És fàcil/difícil de resoldre.

Aquest fred és dur de suportar.

- Quan l'adjectiu va precedit en francès de la forma impersonal «il est», de + infinitif $>$ sense preposició + infinitiu

Il est difficile d'être aviateur.

Il est dur de la supporter.

És difícil ser aviador.

És dur suportar-la.

L'ús dels comparatius (de superioritat, d'igualtat o d'inferioritat) no sol causar problemes de traducció; en tot cas, cal recordar que en una frase francesa negativa podem trobar-nos «si... que»:
Le mulet est plus fort que l'âne.
Il n'est pas si grand que toi.
El mul és més fort que l'ase.
No és tan alt com tu.
Pierre est aussi sage que prudent.
Je suis moins fatigué qu'hier.
Pere és tan sensat com prudent.
Estic menys cansat que ahir.

Però si el comparatiu de superioritat o d'inferioritat va seguit, no d'un adjectiu, d'un pronom o d'un adverbi (com és més habitual), sinó d'una proposició, el grup «que... ne» del francès equival als grups «del que», «que no» en català:
C'était plus facile que je ne croyais.
Il est moins malade qu'il ne pense.
Era més fàcil del que jo creia.
Està menys malalt que no es pensa.

Quant als superlatius, siguen absoluts o relatius, la norma no causa cap problema:

\author{
Cette machine est très bruyante. C'est le ministre le plus éloquent. \\ Aquesta màquina és molt sorollosa. És el ministre més eloqüent. \\ Le football est le sport que j'aime le plus. \\ El futbol és l'esport que més m'agrada.
}

\subsection{La possessió}

La idea de possessió expressada en francès per mitjà de les expressions «à moi», «à toi», «à lui», «à elle», «à nous», «à vous», «à eux», «à elles» (amb el verb «être»), s'expressa en LM per mitjà dels possessius «meu», «teu», «seu»/〈seua», «nostre», «vostre», «seus»/《seues». Però quan «vous» es refereix a «vostè» o «vostès», el grup possessiu «à vous» correspon a «de vostè», «de vostès» $\mathrm{O}$ «seu», «seus»: 
Ces livres ne sont pas à moi, ils sont à vous.

Aquests llibres no són meus, són vostres / de vosaltres / de vostè / de vostès / seus (de vostè) / seus (de vostès).

\section{Resten per exposar algunes observacions:}

- Els determinants possessius francesos «son», «sa», «ses»; «leur», «leurs»; «votre», «vos» (quan «vous» equival a «vostè») es tradueixen per «el seu»/«la seua», «els seus»/«les seues»:

Louis a perdu sa clef.

Lluís ha perdut la seua clau.
Vous avez perdu votre cahier. Vostè ha perdut el seu quadern.

Les enfants ont perdu leurs livres.

Els xiquets han perdut els seus llibres.

- Però «votre» $\mathrm{i}$ «vos» equivalen a «el vostre», «la vostra», «els vostres», «les vostres» quan ens adrecem a diverses persones a qui tutegem, és a dir, quan «vous» és l'equivalent de «vosaltres», «us»:

Mes amis, je vous remercie de votre cadeau.

Amics, us agraïsc el vostre regal.

- Quan ens adrecem a algú (en un diàleg) amb to afectuós o familiar, llavors «mon», «ma», «mes» són équivalents a «meu», «meua», «meus», «meues»:

Tu seras là, ma fille, comme poisson dans l'eau.

Allí seràs, filla meua, com peix a l'aigua.

- El determinant possessiu s'empra més sovint en francès que en català. En el seu lloc, la LM en té prou amb el simple article (és el cas de la roba, les persones o objectes familiars, etc.), al qual afegeix un pronom personal de la mateixa persona que el possessiu que s'ha suprimit:

J'ai mes gants dans ma poche.

Tinc els guants a la butxaca.

Pour saluer ils enlevaient leurs chapeaux.

Per a saludar es llevaven el barret.
Il gagne sa vie comme ça.

Es guanya la vida així.

Tu as fait une tâche sur ta chemise.

$\mathrm{T}$ 'has fet una taca a la camisa.

- Els possessius també poden traduir-se per «propi» $\mathrm{i}$ «mateix»:

Les peuples ne doivent pas renoncer à leur souveraineté.

Els pobles no han de renunciar a la pròpia sobirania.

Les entreprises qui génèrent des déchets et celles qui sont destinées à leur récuperation. Les empreses generadores de residus i aquelles que es dediquen a la recuperació d'aquests mateixos residus.

- «Le vôtre» equival a «el vostre» si «vous» es refereix a «vosaltres»; però «le vôtre» equival a «el seu» (de vostè, de vostès) si «vous» es refereix a «vostè», «vostès»:

Ma moto est en panne, prêtez-moi la vôtre.

La meua moto està avariada, deixeu-me la vostra / deixe'm la de vostè / deixe'm la seua. 


\subsection{Els determinants i pronoms demostratius}

Els determinants o adjectius demostratius francesos i catalans es corresponen de manera general. Les formas simples «ce», «cet», «cette», «ces» poden designar persones o objectes pròxims en el temps o en l'espai («aquest», «aquesta», «aquests», «aquestes»), una mica allunyats («aqueix», «aqueixa», «aqueixos», «aqueixes») o més allunyats («aquell», «aquella», «aquells», «aquelles»).

Ce matin.

Aquest matí.

Il s'adresse toujours à ces dames. Sempre s'adreça a aquelles senyores.
Regardez cette automobile.

Miren aqueix automòbil.

Cet été j'irai à la piscine.

Aquest estiu aniré a la piscina.

Les formes compostes, en canvi, resulten útils per a presentar la direcció o la distància. Quan s'afegeix després del substantiu l'adverbi de lloc «-ci» es dóna una idea de proximitat. En canvi, la idea de llunyania es construeix amb l'adverbi «-là»:

Ce mois-ci je pars en vacances.

Aquest mes marxo de vacances.

Gardez ce livre-là.

Guardeu aquell libre / aqueix llibre.
Ce jour-là il me fatiga.

Aquell dia em va cansar.

En ce temps-là ils buvaient davantage.

En aquell temps bevien molt més.

No obstant això, és observable durant els últims decennis un avanç en francès de l'adverbi «-là» en detriment del «-ci» per a indicar la proximitat, fins i tot entre les preposicions «voici» / «voilà», la qual cosa s'ha de tenir en compte a l'hora de traduir:

\section{Viens-là, je te dis!}

T’he dit que vingues ací!

Pel que fa als pronoms demostratius, hi ha equivalència entre les formes simples, amb l'excepció que el pronom «ce» / «c'» (que precedeix el verb «être» o en les frases interrogatives) no té correspondència en LM:

C'étaient de beaux jeunes hommes.

Eren uns joves macos.

$\begin{array}{ll}\text { Est-ce un livre? } & \text { Qui était-ce? } \\ \text { És un llibre? } & \text { Qui era? }\end{array}$

Però el pronom «ce» + els pronoms relatius «qui», «que» equivalen al neutre «el» 0 «allò» en català:

Ce qui nous arrive est triste.

El que ens passa és trist.

Altres formes compostes són:
Ce qu'il vient de dire est la vérité.

Allò que acaba de dir és la veritat. $\begin{array}{lll}\text { celui qui, celui que } & > & \text { el que } \\ \text { celle qui, celle que } & > & \text { la que } \\ \text { ceux qui, ceux que } & > & \text { els que }\end{array}$ 


\begin{tabular}{|c|c|c|}
\hline celles qui, celles que & $>$ & les que \\
\hline celui de & $>$ & el de \\
\hline celle de & $>$ & la de \\
\hline ceux de & $>$ & els de \\
\hline celles de & $>$ & les de \\
\hline
\end{tabular}

La pipe de Jean et celle de mon frère sont égales. Je préfère ma maison à celle que tu as. La pipa de Joan i la del meu germà són iguals. Peferisc ma casa que la que tens tu.

Quant a les formes compostes dels pronoms demostratius, les que porten l'adverbi «-ci» representen en general la proximitat; les que incorporen la partícula «-là» representen la llunyania:

$\begin{array}{lll}\text { ceci } & > & \text { açò } \\ \text { cela } & > & \text { això, allò } \\ \text { celui-ci } & > & \text { aquest } \\ \text { celui-là } & > & \text { aqueix, aquell } \\ \text { celle-ci } & > & \text { aquesta } \\ \text { celle-là } & > & \text { aqueixa, aquella } \\ \text { ceux-ci } & > & \text { aquests } \\ \text { ceux-là } & > & \text { aqueixos, aquells } \\ \text { celles-ci } & > & \text { aquestes } \\ \text { celles-là } & > & \text { aqueixes, aquelles }\end{array}$

Ceux-ci ont dit oui, ceux-là non.

Aquests han dit que sí; aquells, que no.

\subsection{Els determinants i pronoms indefinits}

El determinant indefinit francès «pas un», «pas une», que expressa amb especial força la idea negativa, és equivalent a «ni un», «ni una» o les seues variants:

Pas un étudiant ne répondit.

Ni un estudiant va respondre.

El pronom indefinit neutre «tout», complement d'objecte directe, correspon a la construcció catalana «ho... tot»:

Je sais tout de lui.

Ho sé tot, d'ell.

El pronom indefinit «on» pot presentar, segons el context, diferents variants:

On dit qu'il fait froid.

Diem (Hom diu / Diuen / Un diu / Una diu) que fa fred.

On est contente de son sort.

Una està contenta de la seua sort.

Ici on vit heureux.

Ací es viu feliç.

On dirait qu'il est content.

Sembla que està content.
On frappe à la porte.

Toquen a la porta.

On le compare à un lion.

Se'l compara amb un lleó. 
Convé detenir-se en els diferents valors d'aquest «on» francès:

- Valor d'impersonal absolut; en català és «hom + 3a persona singular» o «es/se +3 a persona singular o plural»:
On parle prançais.
On loue des chambres.
Hom parla francès.
Es lloguen habitacions.

- Valor de plural indefinit, equivalent a «les gens», en referència a l'ésser humà en general; en català equival a «hom +3 a persona singular», «es/se +3 a persona singular o plural», «3a persona del plural», «la gent/les persones»:

$\begin{array}{ll}\text { Jadis on ne connaissait pas l'avion. } & \text { On ne veut pas travailler ! } \\ \text { En altres temps no es coneixia l'avió. } & \text { No volen treballar! }\end{array}$

Trop souvent on est imprudent.

Amb massa freqüència la gent és imprudent.

- Valor de plural indefinit representat per un nombre més o menys gran de persones, en «quelques-uns», «la plupart», «des gens»; en català es forma amb «(alguns) + 3a persona plural», «hom +3 a persona singular» $\mathrm{o} \ll \mathrm{es} / \mathrm{se}+3 \mathrm{a}$ persona singular o plural»:
On disait qu'il allait pleuvoir.
On disait des bêtises.
(Alguns) Deien que plouria.
Es deien ximpleses.

- Amb valor de singular indefinit, equivalent a «quelqu'un»; en català és «algú» o «3a persona plural»:
On frappe.
On a sonné
Truquen / Algú truca (a la porta).
Han tocat el timbre.

- Per a expressar una acció que sol fer-se d'ordinari; en català es construeixen les frases amb «se + soler en impersonal singular o plural», «soler en impersonal plural», «normalment/d'ordinari + 3a persona plural / 3a persona singular o plural»:

On sème les navets en novembre.

Els naps solen sembrar-se al novembre.

Solen sembrar els naps al novembre.

Normalment/D'ordinari, sembren els naps al novembre.

Normalment/D'ordinari, els naps se sembren al novembre.

- En el llenguatge més aviat familiar, en representació de qualsevol persona singular o plural, sobretot en compte de «je» o de «vous»; a vegades amb un matís de reprotxe, ironia, menyspreu, modèstia, etc.:

On a faim!

Tinc/Tens... tenen gana!

On doit être sage!

Heu de ser formals!
On y va!

Que hi vaig! / Anem-hi!

On devra arriver avant minuit.

Haureu d'arribar abans de les dotze. 
- En representació d'una oració passiva en què no hi ha determinació de subjecte agent:

On connaît l'arbre à ses fruits.

Hom coneix l'arbre pels fruits.

- Finalment, quant a la correspondència de «on» en LM, cal assenyalar que, si bé en francès sol repetir-se cada vegada davant de cada verb, en català pot ometre's aquesta reiteració a partir del segon verb:

On bavardait, on buvait, on jouait, on s'amusait bien.

Hom xerrava, (hom) bevia, (hom) jugava, ens divertíem molt.

\subsection{Els pronoms personals}

En francès, l'ús del pronom subjecte és en principi necessari (excepte en les formes de l'imperatiu) quan no hi ha subjecte-nom; no ho fa així el català, que soluciona les possibles ambigüitats amb la flexió verbal:

Sais-tu qui je suis? C'est moi qui te le dis.

Saps qui sóc? T’ho dic jo.

El pronom personal «vous» mereix algunes observacions. Quan s'empra com a fórmula de cortesia i ens adrecem a una sola persona, correspon a «vostè»; si ens adrecem a diverses persones, correspon a «vostès»:

Comment allez-vous, Madame?

Com està vostè, senyora?
Comment allez-vous, Mesdames?

Com estan vostès, senyores?

Tanmateix, quan «vous» és el plural de «tu», és a dir, si ens adrecem a diverses persones a qui tutegem individualment, correspon a «vosaltres», «us»:

À vous, mes enfants, je vous dirai la même chose.

A vosaltres, fills meus, us diré el mateix.

Per a establir l'equivalència de dos pronoms complements de la 3 a persona cal seguir l'esquema de correspondències següent:

$\begin{array}{lll}\text { Je le lui donne } & > & \text { Li'l done (a ell/ella) } \\ \text { Je le leur donne } & > & \text { Li'ls done (a ells/elles) } \\ \text { Je vous le donne } & > & \text { Li'l done (a vostè/vostès) } \\ \text { Je la lui offre } & > & \text { Li la regale (a ell/ella) } \\ \text { Je la leur offre } & > & \text { Els la regale (a ells/elles) } \\ \text { Je vous l'offre } & > & \text { Us la regale (a vostè/vostès) } \\ \text { Je les lui cache } & > & \text { Li'ls amague (a ell/ella) } \\ \text { Je les leur cache } & > & \text { Els els amague (a ells/elles) } \\ \text { Je vous les cache } & > & \text { Us els amague (a vostè/vostès) }\end{array}$

Els pronoms adverbials (o adverbis pronominals) francesos «en» $\mathrm{i}$ «y» no han de suposar cap problema de traducció en català: «en» i «hi». 
Combien en avez-vous eu de prix? J'en ai eu quatre.

Quants premis ha aconseguit vostè? N'he rebut quatre.

Etes-vous allé à la course de taureaux? J'y suis allé, mais je l'ai regretté.

Va anar als toros? Hi vaig anar, però me'n vaig penedir.

\subsection{Els pronoms relatius}

Els pronoms relatius compostos («auquel»..., «duquel»..., «par lequel»...) són fàcilment identificables. En català la correspondència dels simples és: $a$ ) «qui» / «que»> «que», «el qual», «la qual»..., «qui»; b) «que» (complement objecte directe de persona) > «que», «el qual», «la qual»...; c) «dont» (complement d'un nom, d'un adjectiu o d'un adverbi) es tradueix sovint per «el qual», «la qual», «els quals», «les quals», però també per «del qual», «dels quals», «de la qual», «de les quals», «d'allò que»:

a) Le soleil qui nous éclaire. El sol que ens enllumena.

b) La personne que tu as vue. La persona que has vist.

c) Un musée dont l'entrée était gratuite. Un museu l'entrada del qual era gratuïta.
Les fruits que nous avons mangés.

Les fruites que hem menjat.

C'est toi que je voyais toujours.

Ets tu qui veia sempre.

Des musiciens dont je suis très content.

Uns músics dels quals estic molt content.

\subsection{Els determinants i pronoms interrogatius}

Els adjectius interrogatius francesos «quel ?», «quelle ?», «quels ?», «quelles ?» tenen en català la correspondència següent: «què?», «qui?», «quin?», «quina?», «quins?», «quines?».
Quel téléphone veux-tu?
Quelle est sa maladie?
Quin telèfon vols?
Quina és la seua malaltia?

Quant a l'equivalència dels pronoms interrogatius, cal considerar les persones a què es refereixen, amb tres casos: a) quan «qui ?», «qui est-ce qui ?» són subjecte, la traducció és «qui?»; $b$ ) quan «qui ?», «qui est-ce qui ?» són complement directe, la traducció és «qui?»; c) quan «qui ?», «qui est-ce qui ?» són complement amb preposició, la traducció és la preposició corresponent en LM + «qui».

a) Qui te l'a dit? / Qui est-ce qui te l'a dit?

Qui t'ho ha dit?

b) Qui appelles-tu? / Qui est-ce que tu appelles?

Qui crides?

c) Àqui penses-tu?

À qui est ce bracelet?

En qui penses?

De qui és aquesta polsera? 
Quan es refereix a coses, la diversitat francesa («que ?», «quoi ?», «qu'est-ce qui ?», «qu'est-ce que ?», «quoi est-ce que ?») es redueix en LM a «què?»:

Qu'est-ce qui arrive?

Què passa?

Que dis-tu? / Qu'est-ce que tu dis?

Què dius?

Qu'avez-vous fait? / Qu'est-ce que vous avez fait?

Què ha fet vostè?

De quoi parlez-vous? / De quoi est-ce que vous parlez?

De què parlen vostès?

D'altra banda, les diferents estructures de la interrogació francesa, siga per mitjà del morfema «est-ce que», per mitjà de la inversió del subjecte («Puis-je parler ?») o per mitjà del to de la llengua parlada, solen correspondre a nivells de llengua diferents, cosa que haurà de reflectir-se en la traducció. Tot i ser menys freqüent, també s'haurà de tenir en compte per a la traducció la construcció familiar de la forma oral «-ti ?», que haurà de reproduir-se si és possible en LM amb algun matís de familiaritat. Aquesta forma, que té l'origen en el segle Xv a causa de la pèrdua, en la parla popular, de la «l» final («dit-il»> «dit-i»), disposa d'altres variants: $\left\langle-t^{\prime} y »,\left\langle-t-y »,\left\langle-t^{\prime} i »,\langle-t y »\right.\right.\right.$.
Je suis t'y un imbécile?
On travaille-t-y?
Et penses que sóc estúpid?
Que! Treballant?
Tu joues ou tu n'joues-t'i pas?
Vous êtes-ti prêts?
Hi jugues o què passa?
Que! Esteu llestos?

Convé deixar constància d'algunes construccions específiques, com ara «qui d'autre...» («qui sinó...?»), «que d'autre... ?» («què més...?»), «quoi d'autre ?» («què més?»), «quoi encore ?» («alguna cosa més?»):

Qui d'autre que lui est le coupable?

Qui sinó ell n'és el culpable?
Que d'autre pourrais-je faire?

Què més podria fer jo?

\subsection{Els verbs i les perífrasis verbals}

Ja s'ha avançat que no és propòsit d'aquests apartats realitzar un inventari exhaustiu de les dificultats de traducció d'índole lingüística entre el francès i el català. Tanmateix, com que l'ús i la traducció dels verbs impliquen infinitat de qüestions, tot seguit es plasmen les més útils en gramàtica contrastiva.

a) El verb auxiliar «être» equival a «haver» quan forma part de temps compostos de verbs intransitius, de desplaçament i pronominals. 
Nous sommes allés et revenus.

Hi hem anat i n'hem tornat.

b) Els verbs francesos de moviment «aller», «venir», «envoyer» (seguits d'infinitiu sense preposició), necessiten afegir en la traducció a la LM la preposició «a». Cal recordar ací que, amb el valor de futur immediat, la perífrasi «anar $+\mathrm{a}+$ infinitiu» (malgrat la freqüència amb què s'usa) és castellanitzant i incorrecta (marcada $a m b *)$; en el seu lloc pot emprar-se el futur simple o, si hi cal afegir un valor subjectiu d'immediatesa, expressions com ara «estar a punt de...».

Venez-vous nous accompagner au bar?

Veniu a acompanyar-nos al bar?
Nous allons voir pourquoi.

Vegem per què.

Nous allons assister maintenant au second acte.

Assistirem ara al segon acte (*Ara anem a assistir al segon acte).

Le spectacle va commencer.

La funció està a punt de començar / Comença la funció.

No obstant això, «anar $+\mathrm{a}+$ infinitiu» és genuinament català quan indica moviment.

Je vais dire bonjour à Pierre et je reviens. On sonne, va ouvrir la porte.

Vaig a saludar Pere i torne.

Toquen a la porta, vés a obrir.

c) La idea de passat recent o pròxim s'expressa amb «venir de + infinitif» > «acabar de + infinitiu».

Je viens de la voir avec eux. Nous venons de nous essuyer.

L'acabe de veure amb ells. Acabem d'eixugar-nos.

d) L'aspecte duratiu de l'acció, expressat en francès amb el present continu «être en train de + infinitif», equival en LM a present d'indicatiu.

Ils étaient en train de travailler.

Etes-vous en train de faire la vaisselle? Trevallaven.

Que escureu?

e) «Faillir + infinitif» s'expressa en català amb «de poc + present d'indicatiu».

Il a failli tomber de sa moto.

De poc cau de la moto.

f) La varietat d'usos de «il y a» (tant en present com en altres temps) requereix un estudi detingut de les seues correspondències.

- S'utilitza per a localitzar un objecte en l'espai; si l'objecte és no determinat, els verbs en LM seran els impersonals «haver»o «existir»; si l'objecte és determinat, s'usarà el verb «ser»:

Dans cette forêt il y avait des sangliers. En aquell bosc hi havia senglars.

Sur la table il y a un timbre.

A la taula hi ha un segell.
Dans cette forêt il y avait ces trois sangliers. En aquell bosc hi eren aquests tres senglars.

Sur la table il y a ton timbre.

A la taula és el teu segell. 
- S'usa per a referir-se a un espai o període de temps (generalment passat), en tercera persona:

Il y a deux heures qu'on est arrivés.

Fa dues hores que hem arribat.

Il y avait seulement quelques jours que je l'avais vue.

Feia només uns quants dies que l'havia vista.

g) «Il est» pot expressar una relació de temps, pot indicar l'hora, o pot utilitzar-se en compte de «il y a» en l'expressió que inaugura els contes, en un bon nombre de refranys, o en estil elevat o poètic.
Il est tard.
Il est deux heures.
És tard.
Són les dues.
Il était de grandes villes.
Il est plus de jours que d'années.
Hi havia grans ciutats.
Hi ha més dies que llonganisses.

Il était une fois un bateau.

Una vegada era un vaixell.

h) «Il fait», en expressions referides al temps atmosfèric o cronològic, pot traduir-se de maneres diferents.

- Amb «beau», «mauvais», «chaud», «froid»... significa «fer» en 3a persona del singular:

Il fait beau.

Il fera froid, demain.

Fa bon temps. / Fa bo.

Demà farà fred.

- Seguit de «nuit» $\mathrm{i}$ «jour» equival a «ser de...» en 3a persona del singular:
Il fait nuit.
Il fait jour.
És de nit.
És de dia.

- Però seguit de «sombre» $\mathrm{i}$ «claire» es tradueix per «fer» $\mathrm{o}$ «estar»:

$\begin{array}{ll}\text { Il fait sombre. } & \text { Il fait clair. } \\ \text { Fa fosca. } & \text { Està clar (hi ha claredat). }\end{array}$

Algunes construccions especials mereixen també ser considerades: «il fait bon (de) + infinitif», «il se fait» (en altres expressions referides a temps) i «comment se fait-il que + subjonctif» (equivalent als verbs «ocórrer», «succeir»).

$\begin{array}{ll}\text { Il fait bon de se reposer sur l'herbe. } & \text { Il se fait tard. } \\ \text { És agradable descansar en l'herba. } & \text { Es fa tard. }\end{array}$

Comment se fait-il qu'il parte déjà?

Com és que ja se'n va? / Però, com marxa ja? / Com és això, que se'n va? 
i) «Il faut» és una de les formes d'obligació, que coexisteix amb d'altres: «devoir», «avoir à» i els imperatius dels verbs.

Il faut se reposer après le déjeuner. Després de dinar cal descansar.

Elle devait rentrer avant une heure. Havia de tornar abans de la una.
Il faut que tu viennes demain. Demà has de venir.

Vous avez seulement à répondre. Només ha de respondre.

j) La necessitat s'expressa amb «avoir besoin de» o «falloir». En un sentit general s'empra «il faut»; en un sentit particular, «il + pronom + faut».

Il nous faut une heure pour finir.

On a besoin d'une brosse.

Necessitem / ens cal una hora per acabar. Cal un raspall.

k) L'imperatiu afirmatiu francès equival en català a un imperatiu, però el negatiu es tradueix pel present de subjuntiu.

Va avec lui avant qu'il ne rentre.

Vés amb ell abans que no torne.
Ne trempez pas dans la soupe!

No mulleu en la sopa!

En el cas de l'afirmatiu d'obligació, cal recordar la possibilitat d'utilitzar en català (a més de l'imperatiu normal), la fórmula «a + infinitiu»:

Taisez-vous!

A callar!

\section{Étudions!}

A estudiar!

Juntament amb l'imperatiu negatiu o amb l'ús negatiu de «falloir», la prohibició pot expressar-se de diverses formes:

Ne pas fumer.

No fumeu.
Interdiction de fumer. / Défense de fumer.

Prohibit (de) fumar. / És defès de fumar.

Il est / C'est interdit de fumer / Il est / C'est défendu de fumer.

Està prohibit fumar.

l) Si bé «aimer» sol equivaldre a «agradar», cal tenir present també el verb «plaire».

J'ai toujours aimé le latin.

Mais le grec ne me plaît pas.

Sempre m'ha agradat el llatí.

Però el grec no m'agrada.

m) El verb «arriver» pot presentar diversos significats, segons les construccions de què forme part.

- En forma impersonal, «il + arriver de + infinitif» significa «arribar a + infinitiu»:

Il m'est arrivé de l'entendre plusieurs fois.

Vaig arribar a sentir-lo diverses vegades. 
- En forma personal, «arriver à + infinitif» expressa una acció progressiva, o una acció aconseguida; en ambdós casos equival a «arribar a + infinitiu»:

Elle est arrivée à avoir cinq maris.

Il est arrivé à avoir beaucoup d'argent.

Arribà a tenir cinc marits.

Va arribar a tenir molts diners.

Aquesta última accepció funciona igualment amb «réussir à / parvenir à + infinitif»:

Il a réussi à le faire.

Arribà a fer-ho.

Je parviendrai à l'avoir.

Aconseguiré tenir-lo.

n) «Devenir» $\mathrm{i}$ «finir par + infinitif» es pot traduir per la forma «arribar a + infinitiu», encara que en casos diferents.

Je sais qu'il deviendra riche.

Il finit par le savoir par coeur.

Sé que arribarà a ser ric.

Arribà a saber-ho de memòria.

o) És necessari aturar-se en les possibilitats que ofereix en català l'infinitiu substantivat, que pot procedir d'estructures franceses variades. Alguns exemples ens hi serveixen d'introducció:
L'être et le néant.
Un devoir.
L'ésser i el no-res.
Un deure.
Un être humain
Le lever du soleil.
Un ésser humà.
L'albada.

Però quan això no és possible, el francès ho soluciona així:

- «article + infinitif substantivé»:

J'entends le rire des enfants.

Sent el riure dels infants.

- «substantif» equivalent a aquest infinitiu:
La tombée de la nuit.
Une allure élégante.
El vespre.
Una marxa elegant.

$-\ll$ le fait de + infinitif»:

Le fait de saluer est marque de politesse. Le fait de partir comme ça nous a gêné.

Saludar és senyal de bona educació. $\quad$ El fet d'anar-se'n així ens va molestar.

L'infinitiu francès pot anar precedit també d'un determinant que no siga article:

- «déterminant + infinitif substantivé»:

Je vois leur sourire.

Veig el seu somriure. 
- - déterminant + substantif équivalent»:

Cette marche rapide.

Aquesta marxa ràpida.

- «déterminant + façon de + infinitif»:

Sa façon de partir sans nous avertir.

La seua manera d'anar-se'n sense avisar.

p) La progressió dins de l'acció verbal ofereix solucions diferents en francès i en català. La nostra llengua està predisposada a fer-ho de forma més natural, fins $\mathrm{i}$ tot quan no cal expressar aqueixa idea progressiva. El francès ho expressa amb el verb corresponent més l'ajuda d'expressions com ara: «l'un après l'autre», «peu à peu», «petit à petit», «de plus en plus», «de moins en moins», «progressivement». En LM, l'acció verbal pot expressar-se amb «anar + gerundi».

Sa santé empirait / allait en empirant. Il fait de plus en plus chaud.

La seua salut empitjorava / anava empitjorant. Va fent calor. / Cada vegada fa més calor.

Les arbres s'effeuillent peu à peu. Les invités arrivaient l'un après l'autre.

Els arbres van desfullant-se de mica en mica. Els convidats arribaven l'un darrere l'altre.

q) El començament o la iniciació (aspecte incoatiu) resulten ser més rics en català que en francés.

- «commencer à + infinitif» ofereix diverses possibilitats:

Il commence à pleuvoir.

Comença a ploure. / Està començant a ploure.

- «commencer par + infinitif» es tradueix per:

Aujourd'hui, il a commencé par s'asseoir. Je commencerai par l'écrire sur le tableau.

Avui ha començat per seure.

Començaré per escriure-ho a la pissarra.

- «se mettre à + infinitif» ofereix més possibilitats:

$\begin{array}{ll}\text { Il se mit à travailler. } & \text { Elle se mit à pleurer. } \\ \text { Es posà a treballar. } & \text { Començà a plorar. }\end{array}$

Je me mis à courir.

Vaig arrancar a córrer.

- Els verbs francesos «initier», «commencer»... expressen, com en català, aquest aspecte incoatiu:

Lundi, nous avons initié notre cours.

Vam iniciar el curs dilluns.

- Molts altres verbs francesos, generalment en «-ir / -issant» (2n grup), expressen igualment aquest aspecte incoatiu; el català ha creat per a això 
multitud de verbs de la primera conjugació (en «-ar»), i uns pocs de la tercera (en «-ir»):

$\begin{array}{ll}\text { Elle pâlit. } & \text { Il s'est évanoui. } \\ \text { Es tornà pàl-lida. / Va empal-lidir. } & \text { Va esvair-se. }\end{array}$

- Tant en francès com en català, uns quants verbs (generalment reflexius) $i$ algunes locucions porten en si la idea d'iniciació:

$\begin{array}{ll}\text { Je m'endors. } & \text { Je meurs ! } \\ \text { M'adorm. / Em quede adormit/adormida. } & \text { Em mor! / Em muic! / M'estic morint! }\end{array}$

r) Un dels problemes amb què pot topar-se un traductor és el de les múltiples formes del gerundi. Heus ací els casos més significatius.

- La forma francesa del gerundi en «-ant» pot expressar-se en català per mitjà de la simultaneïtat del mateix gerundi o amb expressions del tipus «mentre...», «tot... + gerundi»:

En enseignant, on apprend.

Tot ensenyant, hom aprèn.

- El gerundi en «-ant» expressa també dues accions que se segueixen immediatament; en català es forma amb «en + infinitiu» o «quan». Aquesta successió immediata pot aparèixer també en francès amb «dès que», «aussitôt après + infinitif passé»; en català equivaldria a «així que»o «tan bon punt»:

J'ai vu l'accident en sortant de la maison. En sortant, je t'ai vu.

He vist l'accident en sortir de casa. Quan sortia, t'he vist.

En arrivant à Paris, il nous téléphonera. Dès qu'on finira, on partira.

Així que arribe a París, ens telefonarà. $\quad$ En acabar, marxarem.

Dès qu'il rentrera, il nous écrira. Aussitôt après avoir mangé, on partira.

Ens escriurà tan bon punt arribe a casa. Marxarem així que acabem de dinar.

- La forma en «-ant» expressa també el mode, que es tradueix en LM amb el gerundi:

Il est arrivé en courant.

Va arribar corrent.

- La forma en «-ant» pot expressar també la condició; en català correspon també a «si + verb conjugat»:

En vous dépêchant, vous serez à l'heure. En collaborant tous, nous n'avons pas besoin de lui. Si us afanyeu, hi arribareu a temps. Si hi colllaborem tots, no el necessitem.

- La forma en «-ant» pot expressar igualment la concessió; en català es construeix amb el gerundi o amb expressions concessives, com ara «encara que» o «tot i que»: 
En faisant semblant de travailler, il perd son temps.

Fent veure que treballa, perd el temps. / Encara que fa veure que treballa, perd el temps.

- La forma en «-ant» serveix per a expressar la causa; en català s’utilitza «gerundi», «si + verb conjugat» o una construcció causal:

En présidant lui [Parce qu'il préside lui], tu peux lire le mémoire.

Presidint ell [Com que presideix ell], pots llegir la memòria.

- La forma en «-ant» serveix per a expressar el medi; en català és el simple gerundi:

C'est en forgeant qu'on devient forgeron.

Treballant al fornall hom esdevé ferrer.

- El gerundi francès construït amb «tout en + -ant» indica tant la simultaneïtat («mentre + verb conjugat», «al mateix temps que + verb conjugat», «tot + gerundi») com l'aspecte concessiu (gerundi o expressió concessiva):

Tout en repassant le linge, elle chantait.

Mentre planxava la roba, cantava.

Tout en paraissant y répondre, elle ne dit que des bêtises.

Encara que faça veure que hi respon, només diu ximpleries.

- El gerundi francès de posterioritat es construeix amb «proposition principale + et + indicatif»; el català no admet el gerundi en aquest cas:

Je suis allé sur ses trousses, et j'ai réussi à l'atteindre.

Vaig seguir els seus passos i vaig aconseguir atrapar-lo.

- El francès també pot expressar el gerundi amb «verbe duratif + à + infinitif»; en català s'usa «verb de duració + gerundi»:

Il passe sont temps à lire.

Passa el temps llegint.

s) El «participe présent» francès pot donar lloc a gal·licismes en català, que s'han fet comuns per la introducció que n'han fet els mitjans periodístics; el seu valor explicatiu no pot convertir-se en especificatiu:

Un décret prohibant la chasse.

Un decret que prohibeix la caça (*prohibint).

Les élèves excellant en français sont priés de partir.

L'alumnat que destaca en francès $(*$ destacant) pot eixir.

Ben sovint, el «participe présent» francès no és més que un «adjectiu verbal»:

Amusant (un film, un livre...).

Divertit.
Eau dormante.

Aigua estancada (mansa).

Reconnaissant (une personne...).

Agraït. 
El participi passat absolut, tant en francès com en català, s'empra a vegades per a substituir una proposició subordinada adverbial.

Tous les billets vendus, le guichet fut fermé.

Una vegada esgotades les entrades, van tancar la taquilla.

Le cours terminé, nous sommes allés faire une promenade.

En acabar la classe, anàrem a passejar.

Aquest participi absolut expressa una circumstància de temps anterior al verb de l'oració principal. Si bé en francès el participi de pretèrit segueix el substantiu, en català sol precedir-lo. Tanmateix, en expressions com ara «vu le décret» o «vu l'heure tardive» (en les que «vu» pot ser considerat preposició) el participi de pretèrit francès precedeix el substantiu. Així mateix, en estil o llenguatge elevat s'utilitza de vegades el participi de pretèrit francès al capdavant $i$ separat del substantiu a què es refereix:

Ôté deux ou trois chapitres, cet ouvrage est excellent.

A banda de dos o tres capítols, aquesta obra és excel·lent.

Venu la fin de l'hiver, la troupe toute entière partit pour l'Angleterre.

En arribar la fi de l'hivern, l'exèrcit al complet marxà cap a Anglaterra.

t) La traducció de les construccions impersonals franceses amb «on»o passives es resol en català $\mathrm{amb}$ formes reflexives:

Aucune candidature ne sera admise après 14 heures.

No s'admetrà cap candidatura després de les 14 hores.

Autrefois on faisait la vendange avant septembre.

Antigament la verema es feia abans de setembre.

\subsection{Els adverbis i locucions adverbials}

Aquest apartat intenta traslladar el més fonamental dels adverbis, des de l'aspecte contrastiu, entre el francès i el català.

a) «Aussi» com a adverbi i «aussi» al principi d'una proposició no tenen la mateixa equivalència; en català corresponen a «també» i «per això» (amb totes les variants, tant del primer com del segon).
Jacques est malade, Noëmi l'est aussi.
Il n'était pas content, aussi il est parti.
Jaume està malalt, Noemí també ho està.
No estava content, per això se'n va anar.

b) «À demie» $\mathrm{i}$ «à moitié» funcionen de manera idèntica, però això depèn de la seua posició en la frase. Davant d'un adjectiu o d'un participi es tradueixen per «mig»; després d'un verb es tradueixen per «a mitges».

Il est à moitié fou.

Està mig boig.
Je l'ai lu à moitié.

Ho he llegit a mitges. 
c) No ha de confondre's l'ús de «comme» (exclamatiu, idèntic a «que») i «comment» (interrogatiu).

Comme / Que ces bois sont beaux! Que bells són aqueixos boscos!

Comment vous dites?

Com diu vostè?

d) L'adverbi «mieux» pot correspondre a frases diferents, encara que no ha de confondre's amb l'adjectiu «meilleur» / «meilleure», traduïble igualment per «millor».

Il conduit mieux que les autres.

J'ai fait de mon mieux.

Condueix millor que els altres.

Vaig fer el que vaig poder.

C'est Paul qui chante le mieux. Pau és el que millor canta.

Nous allons de mieux en mieux.

Estem cada vegada millor.

e) «Même» equival en català a «fins»», «fins i tot», «àdhuc».

Mêmes les femmes votèrent non.

Même ici, je sens le froid.

Fins i tot les dones votaren que no.

Àdhuc ací sent el fred.

f) L'equivalència de «ne... même pas», «pas même» és «ni tan sols», «ni»».

Je n'ai même pas commencé.

Ni tan sols he començat.
Je ne le connais même pas.

$\mathrm{Ni}$ el conec. / Ni tan sols el conec.

Je ne sais même pas s'il viendra.

$\mathrm{Ni}$ tan sols sé si vindrà.

g) Els adverbis negatius no suposen problema de traducció, però sí algunes construccions que els contenen.

- Quan inauguren la frase, «pas de» se sol traduir per «res de»; i «plus de», per «prou de» (a més de la possibilitat de traduir totes dues per la negació del verb «voler»).

Plus de racisme!

Non, merci. Pas de cognac.

Prou racisme!

No, gràcies. Res de conyac. / No vull conyac.

- La segona partícula negativa «point» substitueix «pas» quan es vol expressar la negació amb més energia, i el seu ús és molt menys freqüent.

Ne m'en parlez point.

No me'n parleu.

- La partícula «ne» no té valor pròpiament negatiu quan funciona com a expletiu.

- En subordinades precedides de «plus que», «moins que», «meilleur que», «ne pas contester», «ne pas douter», «ne pas nier», «peu s'en faut»:

Il en a plus qu'il ne convient. En té més del que convé.
Peu s'en faut qu'il n'ait manqué le train.

De poc (no) perd el tren. 
- En oracions que són complement de verbs que expressen temor, dubte o impediment:

Je crains qu'il ne vienne.

Tem que vindrà.

És evident la diferència amb la negativa:

Je crains qu'il ne vienne pas.

Tem que no vindrà.

- Després de «avant que», «de peur que», «de crainte que» (quan hi ha dubte sobre la realitat de l'acció) i «que» (en el sentit de «sense que»):

De peur qu'il ne parle.

De por que parle / que puga parlar.
Vous ne bougerez pas que je ne vous le dise. No es mourà sense que jo li ho diga.

- A vegades, només apareix en la frase francesa la primera partícula negativa; convé tenir-ne presents els casos per a no confondre aqueixes frases amb d'altres de «ne» expletiu.

- Quan la negació es completa amb la presència en la frase d'altres paraules de sentit negatiu:

Je ne sais rien; personne ne l'appela.

No en sé res; ningú no el va cridar.

- Després del pronom o de l'adjectiu interrogatiu:

Qui n'en ferait autant?

Qui no faria el mateix?

- En frases que expressen pesar o desig:

Qu'il ne le regrette, lui!

À Dieu ne plaise!

Que ell no se'n penedisca!

Déu no ho vulga!

- Amb els verbs «cesser», «oser», «pouvoir», «savoir», en temps simple $\mathrm{i}$ sense complement o seguits d'un infinitiu:

Je ne sais. Je n'ose le dire.

No ho sé. No m'atrevisc a dir-ho.

- Després del verb «avoir» seguit de «que»:

Je n'ai que faire de vos dons.

No puc fer res amb els vostres presents.

- En frases com ara:

Je n'en reviendrai pour longtemps.

No tornaré per molt de temps.
Depuis que je ne l'ai écouté.

Des que no el vaig escoltar. 
Il y a trois mois que tu ne l'as vu.

Fa tres mesos que no l'has vist.

- Després de «si», amb el verb en temps compost:

S'il ne l'avait aimé.

Si no l'haguera estimat.

- En frases fetes del tipus:
Il ne dit mot.
Qui ne dit mot consent.
No amolla paraula.
Qui calla, atorga.
Ne vous en déplaise.
Qu'à cela ne tienne.
Mal que li pese.
Per mi no us cal patir.
Unje-ne-sais-quoi.
N'avoir cure, n'avoir garde.
Un no sé què.
No preocupar-se'n, no tenir-ne cura.
N'importe.
Si je ne me trompe.
Tant se val.
Si no m'equivoque.
Si je ne m'abuse.
Sicen'est.
Si no m'enganye.
Si no és.

h) «Ne... que» expressa la restricció i equival a les locucions catalanes «només», «solament», «tan sols».

Il ne parle que français

Elle n'a que vous au monde.

Solament parla francès.

Només té a vostè en el món.

i) La locució «ne... plus» marca el cessament d'una acció o d'un estat. En català es tradueix per «no... més», «ja no».

Il ne viendra plus personne.

No vindrà ningú més.
Nous n'avons plus de monnaie.

Ja no ens queda gens de solt.

j) Els adverbis «voici» i «voilà» estan carregats de valor demostratiu, i la seua traducció s'ha anat ajustant amb el pas del temps a l'ús natural de la LM. Heus ací algunes equivalències:

- «Heus ací», «heus aquí», «vet ací», «vetací», «vet aquí», «vetaquí», «vetallà»... Cal afegir-hi les formes personalitzades:

Me voici, te voilà, le voilà, la voilà.

Vet-m'ací, heus-vos aquí, vet-l'aquí, vet-los allà.

Les formes en desús hauran de substituir-se per d'altres de més precises.

- «Aquest és», «aqueix és», «aquell és», quan es vol designar:

Voici mon livre et voilà le vôtre.

Aquest és el meu llibre i aquell és el de vostè. 
- Quan l'objectiu és situar: «aquí és», «allí és», «ací ve», «allà va».

Voici ma mère (qui vient).

Aquí ve ma mare.

- Quan es lliura un objecte: «ací + tenir», «aquí + tenir», «allí + tenir». Si l'objecte és llançat hi correspon «allà va...»:

Voici votre billet.

Ací té vostè el bitllet.

- Altres fórmules: «ja», «quin», «quina», «quins», «quines», «des de fa».
Voici le printemps qui arrive.
En voilà une chaleur!
Ja ve la primavera.
Quina calor!

Voilà deux heures que j'attends.

Estic esperant des de fa dues hores.

k) La riquesa expressiva de l'adverbi francès «naturellement» ha de tenir-se molt en compte en les traduccions.

- Amb valor de «conformément aux lois naturelles», «par un enchaînement logique et naturel», equival a «naturalment», en frases com ara:
Tout est explicable naturellement.
J'étais naturellement porté à le faire.
Tot s'explica naturalment.
Em sentia naturalment inclinat a fer-ho.

- Amb valor de «nécessairement», «inévitablement», «évidemment», en català pot traduir-se per «naturalment», «com és natural», «com és normal», «evidentment», «és clar»:

Je n'ai rien dit, naturellement. Il a répondu, naturellement.

No he dit res, és clar. Com és natural, ha contestat.

- Amb valor de «d'une manière spontanée, aisée», «sans affection ni recherche», es tradueix per «amb naturalitat». Cal anotar-hi dues observacions: «tout naturellement» equival a «amb tota naturalitat», $\mathrm{i}$ «si naturellement» correspon a «amb tanta naturalitat». Vegem-ho en els exemples:

Il a répondu naturellement. Il sait écrire naturellement.

Va respondre amb naturalitat. Sap escriure amb naturalitat.

Il parlait tout naturellement. Il me l'a raconté tout naturellement.

Parlava amb tota naturalitat. M'ho contà amb tota naturalitat.

Il la tutoyait si naturellement qu'il la surprenait.

La tutejava amb tanta naturalitat que la sorprenia.

- Amb valor de «conformément à la nature», «conformément au naturel», «par une impulsion naturelle», en català equival a «per naturalesa»: 
L'homme est naturellement égoïste.

L'home és egoista per naturalesa.
Il était courageux naturellement.

Era valent per naturalesa.

- Amb valor de «comme il était prévu», es tradueix per «com es podia esperar», «com se suposava»:

Cet incorrigible étourdi a naturellement manqué le train.

Aquest incorregible despistat, com es podia esperar, ha perdut el tren.

\subsection{Algunes proposicions independents}

a) La presentació i la insistència. Sabem que les fórmules franceses de presentació per excel·lència són «c'est», «ce sont», «c'était», seguides d'un nom o d'un pronom; en català s'hi empren simplement «és», «són», «era». No obstant això, en frases en què es pretén posar en relleu algun element o insistir sobre aquest, s'hi poden introduir idees de lloc, de temps o de manera. En aqueixos casos, «que» equival a «on», «quan, «com».

C'est là qu'il est entré.

Allí és on va entrar.
Ce fut alors qu'il sorti.

Fou aleshores quan va eixir.

C'est ainsi que nous voudrions vivre.

Així és com voldríem viure.

Combinada amb els pronoms relatius «qui» (subjecte) $\mathrm{i}$ «que» (objecte directe), l'expressió de la insistència no ha de presentar problemes de traducció («qui»o «que» en català).

C'est le facteur, que tu vois au loin.

Qui veus allà lluny és el carter. / És el carter, qui veus allà lluny.

C'est son frère, qui le dépasse.

El seu germà és el qui el passa al davant. / És el seu germà, qui el passa al davant.

b) L'expressió del prec. Es construeix en francès amb «prier de / demander de / dire de... + infinitif». En català s'usen tant «de + infinitiu» com la subordinada introduïda per la conjunció «que»; ambdues construccions es consideren correctes, encara que és preferible la primera (sobretot en la llengua escrita).

Je vous prie de m'excuser.

Li pregue d'excusar-me. / Li pregue que em disculpe.

Demande-lui de le faire.

Demana-li de fer-ho. / Demana-li que ho faça.

c) L'expressió del mandat es construeix en francès amb «commander de / ordonner de / exiger de... + infinitif». En català equival a «manar que / ordenar que / exigir que + subjuntiu», o bé «manar de / ordenar de / exigir de + infinitiu»: 
Je te commande de rentrer avant.

Et mane que tornes abans. / Et mane de tornar abans.

Je lui ai ordonné de venir.

$\mathrm{Li}$ vaig ordenar que vinguera. / Li vaig ordenar de venir.

Je lui exigerai de l'emporter.

Li exigiré que s'ho emporte. / Li exigiré d'emportar-s'ho.

d) L'expressió de cortesia ofereix múltiples versions, segons que es tracte d'una conversa directa, telefònica o correspondència comercial. En la pràctica, el futur de cortesia pot substituir-se pel condicional o també pel present («li podria...?», «li puc...?»).

- En llengua parlada, les correspondències són les següents:

«plus-que-parfait de l'indicatif» > «imperfet d'indicatiu»

«conditionnel de politesse» > «condicional de cortesia»

«futur de politesse» > «futur / condicional de cortesia»

J'étais venu vous demander un service.

Venia per demanar-li un favor.

Je voudrais vous demander un service.

Voldria demanar-li un favor.

Je pourrai te demander un renseignement?

Podria demanar-te una informació?

- Al telèfon, les fórmules són diferents (tot i que, amb el servei automàtic, algunes deixaran de ser usades):

Ne quittez pas, je vous en prie.

No es retire, per favor.

Je vous prie de rappeler.

Torne a telefonar, per favor.
Veuillez essayer de nouveau. Intente-ho de bell nou, per favor.

Je vous prie de refaire le numéro.

Torne a marcar per favor.

Veuillez raccrocher / Raccrochez, s'il vous plaît.

Penge, per favor.

- En la correspondència postal, siga comercial o d'un altre tipus, cal atenir-se a les convencions o fórmules de cortesia més convenients a cada cas i en cada idioma. Les opcions dependran bàsicament del tipus de destinatari: amic o familiar (A), persona coneguda de més edat (B), persona desconeguda o amb la qual es manté poca relació $(\mathrm{C})$, persona important o amb càrrec oficial (D). Ens interessa ressaltar ací, sobretot, els formulismes del principi i del final de les cartes:

(A)

Chers parents,

Benvolguts pares,
Je réponds à ta lettre.

Conteste a la teua carta. 
Je vous embrasse tous.

Un bes per a tots.

(B)

Cher Monsieur,

Benvolgut senyor,
Amitiés.

Salutacions.

Je réponds à votre lettre $d u \ldots$.

Consteste a la vostra carta del...

Je vous adresse mon amical souvenir.

Una salutació ben cordial.

(C)

Monsieur,

En réponse à votre lettre $d u . .$.

Senyor,

En resposta a la vostra carta del...

Veuillez agréer, Monsieur, mes sentiments dévoués.

Molt atentament,

(D)

Monsieur le Directeur,

Senyor director,

J'ai l'honneur de répondre à votre lettre...

És per a mi un plaer respondre a la vostra carta...

Je vous prie d'accepter, Madame, l'expression de ma plus haute considération.

Respectuosament,

\subsection{Les preposicions}

a) La preposició francesa «à» pot tenir el valor de «amb» o «de» en català.

Un café au lait.

Un cafè amb llet.

Marcher à pas lents.

Caminar amb pas lent.

Une machine à écrire.

Una màquina d'escriure.
Écrire au crayon.

Escriure amb llapis.

Cette maison est à Jean.

Aquesta casa és de Joan.

Ceci est facile à faire.

Açò és fàcil de fer.

El complement directe de persona francès es construeix sense preposició, com en català. No obstant això, usarem de forma restringida la preposició «a» en casos en què resulte necessari evitar ambigüitats (normalment davant dels pronoms forts).

Vous aimez vos oncles?

Qui appelles-tu?

Estimeu els vostres oncles?

Qui crides?

Je t'appelle, toi !

C'est moi qui le corrigerai.

Et cride a tu! Jo el corregiré a ell.

b) La preposició «de» sol correspondre a la mateixa en LM, encara que pot no tenir cap equivalència, com en els casos següents:

Ils n'ont pas de problèmes.

No tenen problemes.
Ici il n'y a pas de solution.

Ací no hi ha solució. 
Il n'est pas facile de réussir.

No és fàcil d'aprovar.
Il suffit de lire ce livre.

Només cal llegir aquest llibre.

Mon intention était de voyager seul.

La meua intenció era viatjar sol.

Però «de» pot funcionar com a «des de», «de» o «per a» en català:

Du château on domine toute la vallée.

Del castell es domina tota la vall.

Du point de vue de ma fille, c'est non.

Des del punt de vista de la meua filla és que no.

Il a même le temps de jouer au tennis.

Fins i tot té temps per a jugar al tennis.

c) La preposició francesa «en» correspon moltes vegades a la mateixa en català, encara que pot traduir-se per «de» en alguns casos; per exemple, per a indicar el material amb què està fet un objecte, $\mathrm{o}$ en altres expressions.

Sa robe était en laine.

J'ai envie de partir en voyage.

El seu vestit era de llana.

Tinc ganes d'anar-me'n de viatge.

d) «Pour» i «par» solen confondre's en LM. Cal recordar que «par» indica la idea de «a través» o introdueix l'agent de la veu passiva (és a dir, sempre «per»). «Pour» significa, segons els casos, tant «per» com «per a».

Il est passé par le jardin.

Va passar pel jardí.

Il fut puni pour sa lâcheté.

El van castigar per la seua covardia.

Il est mort pour sa patrie.

Va morir per la seua pàtria.

Je le fais pour toi.

Ho faig per tu.
Elle a été construite par Eiffel.

Fou construïda per Eiffel.

Je vous le laisse pour dix euros.

Li ho deixe per deu euros.

Ma passion pour la lecture.

La meua passió per la lectura.

Tiens, c'est pour toi.

Pren, és per a tu.

e) Per a indicar el moment de la jornada i la data, es fa necessari utilitzar en LM la preposició corresponent (que no s'usa en francès).

Le matin, l'après-midi, le soir.

Paris, le 12 avril 2011.

Al matí, a la vesprada, a la nit.

París, 12 d'abril de 2011.

f) «Depuis» es tradueix per «des de», o per «des de fa» quan expressa la idea de duració amb un numeral.

Depuis le matin jusqu'au soir.

Depuis deux jours qu'elle ne sort pas.

Des del matí fins a la nit.

No surt des de fa dos dies.

g) La preposició francesa «chez» sol correspondre a «a casa (de)», «de casa de»; però, emprada en un sentit figurat, es tradueix per «en», «entre», «en terra de». Tampoc no ha d'oblidar-se l'ús que se'n fa en francès per a indicar la visita a alguns professionals. 
Je suis chez moi.

Sóc a casa.

Elle vient de chez ses parents.

Ve de casa dels seus pares.

Je vais chez de médicin.

Vaig a cal metge.
Chez les Belges...

A Bèlgica.

Chez les paysans il y a plus de noblesse.

Entre els pagesos hi ha més noblesa.

h) De vegades cal prestar atenció a l'ús de la preposició «sur», que té diverses solucions en LM i que sol provocar algunes faltes (marcades amb *).

Le drapeau européen figure, à côté du drapeau tricolore, sur la photo officielle du président de la République.

La bandera europea figura, al costat de la bandera tricolor, en la foto oficial del president de la República.

La bandera europea figura, al costat de la bandera tricolor, sobre la foto oficial del president de la República.*

Elle avait accroché son tableau sur le mur, juste à côté de celui de Matisse.

Havia penjat el quadre a la paret, just al costat del de Matisse.

Havia penjat el quadre sobre la paret, just al costat del de Matisse.*

Ce soir, sur TV5, un programme culturel pour vous tous.

Aquesta nit, en TV5, un programa cultural per a tots vostès.

\subsection{Les conjuncions}

La conjunció «mais» necessita per si sola un apartat. Després d'una oració afirmativa, pot donar-se el cas que la segona part continga implícit el mateix verb o un altre de diferent; en ambdós casos es tradueix per «però» (i les seues variants).

Elle est sympa, mais un peu timide.

És simpàtica, però una mica tímida.
Elle est sympa, mais elle ne travaille pas. És simpàtica, però no treballa.

Després d'una oració negativa, si un sol verb abraça les dues parts, «mais» es tradueix per «sinó»; si es tracta de dos verbs distints, equival a «però», «sinó que».

Ce n'était pas Michel, mais Pierre.

No era Miquel, sinó Pere.
Elle n'est pas blonde, mais rousse.

No és rossa, sinó pèl-roja.

Elle ne travaille pas, mais perd son temps à lire des bandes dessinées.

No treballa, sinó que perd el temps llegint historietes.

Je ne le nie pas, mais je me réaffirme totalement.

No ho negue, sinó que m'hi reafirme totalment.

«Non seulement... mais» pot donar lloc a quatre combinacions, segons si un sol verb abraça les dues parts de la frase, o si hi ha dos verbs distints (un per a cada part). Els resultats són, respectivament: 
non seulement..., mais aussi > no sols..., sinó també

non seulement..., mais encore $>$ no sols..., sinó a més

non seulement..., mais aussi $>$ no només..., sinó que també

non seulement..., mais encore $>$ no sols..., sinó que a més

Non seulement sympa, mais aussi jolie. Non seulement sympa, mais encore jolie.

No només simpàtica, sinó també bonica.

No sols simpàtica, sinó, a més, bonica.

Non seulement elle chante, mais aussi elle danse.

No sols canta, sinó que també balla.

Non seulement elle chante, mais encore elle danse.

No sols canta, sinó que, a més, balla.

És l'ocasió de recordar algunes locucions i frases fetes amb «mais»:

Mais oui!

És clar que sí! / Naturalment! / Sens dubte!

Mais non!

És clar que no! / De cap de les maneres! / Ni pensar-hi!

Il n'y a pas de mais qui tienne. N'en pouvoir mais (adv.).

No hi valen peròs.

No poder més. / No poder fer-hi més.

\subsection{Les oracions subordinades relatives}

Convé deixar constància de les correspondències entre temps verbals per a les frases subordinades de relatiu.

«futur simple» $>$ «present de subjuntiu»

«futur antérieur» > «perfet de subjuntiu»

«conditionnel présent» > «imperfet de subjuntiu»

«conditionnel passé» > «plusquamperfet de subjuntiu»

Dites ce que vous voudrez.

Diga vostè el que vulga.
Qui l'interrogerait aujourd'hui, n'en tirerait pas un mot. Si algú li preguntara avui, no li trauria ni una paraula.

En una subordinada relativa (precedida per un superlatiu o pels adjectius «seul», «premier», «dernier»), on el francès utilitza el «subjonctif présent» el català fa servir, en la majoria dels casos, l'indicatiu.

C'est le plus beau paysage que j'aie vu.

És el paisatge més bell que he vist.

Ma sœur est la seule personne qui puisse me comprendre.

La meua germana és l'única persona que em pot entendre. 


\subsection{Les oracions subordinades temporals}

Ja s'ha exposat anteriorment la simultaneïtat, expressada en francès per mitjà de «en + participe présent» (equivalent en LM a «en + infinitiu»), o per mitjà de la construcció «tout + gérondif» (equivalent al gerundi o a «mentre»). No obstant això, també poden expressar-se les accions simultànies amb «à peine» $\mathrm{i}$ «pas encore».

J'avais à peine étudié une heure que je dus m'arrêter.

Quasi no havia estudiat una hora i vaig haver de deixar-ho.

Ils n'étaient pas encore partis que la police appela.

Tot just havien marxat que va telefonar la policia.

Si la idea és de posterioritat, la correspondència de temps verbal entre el francès $\mathrm{i}$ el català després d'una conjunció temporal és total. Val a dir que l'opció de present de subjuntiu és l'habitual en la llengua parlada; segons Badia (1985: 266-267), el subjuntiu hauria de matisar una expressió més problemàtica, mentre que el futur indicaria una expressió més segura.

«futur simple» > «futur» / «present de subjuntiu»

«futur antérieur» > «futur perfet» / «present de subjuntiu»

Quand tu me rendras ce livre, je t'en prêterai un autre.

Quan em tornaràs el llibre, te'n deixaré un altre.

Dès que je serai arrivé, je t'écrirai.

Així que hauré arribat, t'escriuré.

\subsection{Les oracions subordinades condicionals}

En la llengua escrita, les correspondències entre els temps verbals que usen el francès i el català estan perfectament definides. No obstant això, és observable en la llengua parlada que, en l'oració subordinada, estan molt esteses les formes del subjuntiu en compte de les de l'indicatiu.

«si + présent, futur simple» $>\langle$ «si + futur/present»

«si + imparfait, conditionnel présent» $>\ll s i+$ imperfet d'indicatiu/subjuntiu, condicional»

«si + plus-que-parfait, conditionnel passé» > «si + plusquamperfet d'indicatiu/ subjuntiu, condicional perfet»

Segons que es tracte, per aquest ordre, d'hipòtesi real, possible o irreal, les correspondències seran:

Si tu peux, nous irons au théâtre.

Si pots, anem al teatre. / Si pots, anirem al teatre. 
Si tu pouvais, nous irions au théâtre.

Si podies, aniríem al teatre. / Si pogueres, aniríem al teatre.

Si tu avais pu, nous serions allés au théâtre.

Si havies pogut, hauríem anat al teatre. / Si hagueres pogut, hauríem anat al teatre.

Després de l'expressió «comme si», l'equivalència és la següent (indicatiu en LO i subjuntiu en LM):

Il parle comme s'il était notre patron.

Parla com si fóra el nostre cap.

Il parlait comme s'il était notre patron.

Parlava com si fóra el nostre cap.

Il parlait comme s'il avait été notre patron.

Parlava com si haguera estat el nostre cap.

Resulta adequat incloure ací el grup «si jamais...», que pot traduir-se de diferents maneres en català: «si alguna vegada...», «si algun dia...», «si un dia...», «com (un dia) + subjuntiu», «si + arribar a + infinitiu», «si mai...».

Si jamais je le rencontre!

Si un dia el trobe!

Si jamais tu as l'occasion, va la voir.

Si mai tens l'ocasió, vés a veure-la.
Si jamais il te méprise!

Si t'arriba a menysprear!

\subsection{La causa i la conseqüència}

Les partícules franceses «puisque» $\mathrm{i}$ «comme», que indiquen una causa expressada ja anteriorment, solen traduir-se en LM per «ja que», «com que» $\mathrm{i}$ altres expressions semblants.

Puisque tu insistes, ça doit être important.

Com que insisteixes, deu ser important.

La conjunció de coordinació «car» es tradueix molt sovint com «car», «perquè», o fins i tot «que».

Parle plus haut car je ne t'entends pas.

Parla més fort, que no et sent.

La locució «étant donné» funciona igualment com a causal.

Notre amitié étant donnée.

Atesa la nostra amistat.

Étant donné qu'il ne voulait pas l'avouer.

Atès que no volia confessar-ho.
Étant donné son âge.

Atesa la seua edat.

Étant donné les circonstances.

Ateses les circumstàncies. 


\subsection{La concessió}

Les proposicions subordinades concessives són introduïdes en francès per diverses conjuncions, adverbis o locucions.

a) Tenen valor concessiu les conjuncions «bien que», «quoique», «malgré que», «alors même que», «même sì,, «quand même». En català, caldria classificar-les en universals («encara que», «per més que», «a pesar que», «tot i que»), literàries («malgrat que», «bé que», «per bé que», «si bé») i arcaiques («jatsia», «jatsia que», «anc que»).

Bien qu'il ait cent ans, il travaille. Encara que tinga cent anys, ell treballa.
Je me mettrai en route même s'il neige. Em posaré en marxa, encara que neve.

Il dit qu'il partira quand même il pleuvrait.

Diu que se n'anirà encara que ploga.

b) Indica també la concessió l'adverbi «tout» davant d'un adjectiu, i en aquest cas el català prefereix «si bé».

Tout savant qu'il est, il dit des sottises.

Si bé és savi, diu ximpleses.

c) Són concessius «quelque» $\mathrm{o}$ «si» davant d'un nom o adjectiu. El català sol usar «per més».

Quelque / Si riche que vous soyez, votre sort ne me fait pas envie. Per més ric que siga vostè, no envege la seua sort.

Quelques bons juges que vous les croyez, ils peuvent se tromper. Per més bons jutges que vostè els considere, es poden equivocar.

d) L'adverbi «tout» pot prendre un valor concessiu davant d'un gerundi, un adjectiu, un participi o un adverbi (ja s'ha vist en l'apartat referit als verbs).

Tout en riant, il lui a dit la vérité. Malgrat que reia, li ha dit la veritat.

Tout loin qu'il est, il nous voit. Tot i que és lluny, ens veu.

e) La locució «avoir beau + infinitif» equival en català a «per més... que», «per més que», «per molt... que», «per molt que».

Tu as beau être riche, je te déteste. Per més ric que sigues, jo et deteste.

Tu auras beau être rapide, il te gagnera. Per molt ràpid que sigues, et guanyarà.
Vous aurez beau dire et beau faire... Per més que digueu i feu...

Ils ont beau me taquiner, moi je résiste.

Per molt que em burxen, jo resistisc. 


\subsection{La comparació}

Més enllà dels graus de comparació de l'adjectiu (ja exposats més amunt), existeixen en francès algunes expressions per a comparar proposicions.

a) L'expressió francesa «autant que + subjonctif», correspon en LM a «tant com». No s'ha de confondre amb «aussi... que», que correspon a «tan... com».

Ils travaillent autant qu'ils peuvent. Elle est aussi belle que sa mère.

Treballen tant com poden. És tan bonica com sa mare.

b) Les expressions franceses «plus... plus», «moins... moins», «plus... moins», «moins... plus» funcionen com les catalanes «com més... més», «com menys... menys» (o combinades).

Plus il a de l'argent, plus il en veut.

Plus tu l'expliques, moins je le comprends. Com més diners té, més en vol.

Com més ho expliques, menys ho entenc.

c) L'expressió «d'autant plus / moins... que» es correspon amb la catalana «tant més / menys... com més / menys».

Votre salaire sera d'autant plus élévé que le travail sera plus pénible.

El seu salari serà tant més elevat com més penós siga el treball.

Tanmateix, és més habitual en francès l'ús de la locució «plus... plus...».

Plus le travail sera pénible, plus votre salaire sera élevé.

Com més penós siga el treball, més elevat serà el seu salari.

\subsection{Les abreviatures, les sigles i els acrònims}

En l'antiguitat i en l'edat mitjana s'utilitzaven les abreviatures per guanyar temps i estalviar papir o pergamí, i s'alternaven diferents sistemes: l'abreviatura per sigles $(\mathrm{DN}=$ Dominus Noster $)$, per contracció o supressió de lletres a l'interior de la paraula $($ eps $=$ episcopus $)$, per suspensió o de paraula inacabada $($ aut $=$ autem $)$, per signes col-locats damunt de lletres $(\stackrel{\mathrm{g}}{=}=$ gratia $)$, o per mitjà de signes especials $(\mathrm{p} 9=$ post $)$. Els primers impressors van tractar de reproduir fidelment les abreviatures dels manuscrits, la qual cosa els va obligar a fondre molts tipus especials. Les abreviatures es van utilitzar sovint en els incunables, però van anar disminuint en el segle XVI i van desaparèixer quasi per complet en el XVII.

Es coneix amb el nom de sigla cada una de les lletres inicials d'un grup de paraules, que s'usen convencionalment unides en compte de l'expressió sencera. Les sigles es diferencien de l'abreviatura en el fet que es llegeixen com una sola paraula, bé amb la pronunciació normal (ONU), bé pronunciant-ne els sons singulars de cada una de les lletres (SA). Cal advertir que en francès és norma habitual lletrejar, però no així en català. 
Per la seua banda, l'acrònim és una paraula formada per les lletres o síl·labes inicials de les parts d'un terme compost. Així, radar es va formar a partir de RadioDetection and Ranging. També poden formar-se acrònims a partir de les lletres terminals, com va succeir amb motel, format a partir de motor hotel.

En l'actualitat, les abreviatures tenen un ús limitat en les llengües i la seua pervivència depèn en bona part de l'evolució de cada idioma. Per això, les que es presenten tot seguit (moltes de les quals són ja vetustes), acompanyades d'alguns acrònims i sigles, poden servir com una petita base de documentació terminològica; el motiu d'incloure-les ací és, precisament, fer-les visibles i facilitar-ne l'ús. Una consulta obligada haurà de ser la base de dades europea RTD-Acronyms Database, que conté complida informació sobre aquest tema, i en context català, la publicació Abreviacions (Capó i Veiga, 2005). De tota manera, en traducció tot és «actual», és a dir, podem tenir la necessitat d'abordar un text antic que continga algunes abreviatures en desús, per això la importància de tenir-les totes presents. Per a aconseguir-ho, res millor que tenir a mà la documentació pertinent, que -en molts casos- procedeix dels diferents manuals d'estil que es van publicant periòdicament.

\section{Algunes abreviatures, sigles i acrònims francesos}

\section{Temes diversos}

$\begin{array}{ll}\text { 7bre, 8bre } & \text { septembre, octobre } \\ \text { 9bre, Xbre } & \text { novembre, décembre } \\ \text { A } & \text { ampère } \\ \text { A.D. } & \text { Anno Domini } \\ \text { A.E. } & \text { Affaires étrangères } \\ \text { A.F. } & \text { Allocations familiales } \\ \text { A.F.P. } & \text { Agence France Presse } \\ \text { A.J. } & \text { Auberges de Jeunesse } \\ \text { A.S. } & \text { Assurances sociales } \\ \text { A.T. } & \text { Ancien Testament } \\ \text { apr. J.-C. } & \text { après Jésus-Christ } \\ \text { Arrt. } & \text { Arrondissement } \\ \text { av. J.-C. } & \text { avant Jésus-Christ } \\ \text { B.E.P.C. } & \text { Brevet d'Études du Premier Cycle } \\ \text { B.I.T. } & \text { Bureau international du travail } \\ \text { B.O. } & \text { Bulletin officiel } \\ \text { B.U.S. } & \text { Bureau universitaire de statistiques } \\ \text { Bde. } & \text { Brigade } \\ \text { BENELUX } & \text { Union douanière de la Belgique, du Luxembourg et des Pays-Bas } \\ \text { c. à d. } & \text { C'est-à-dire } \\ \text { C.C. } & \text { Corps consulaire } \\ \text { C.D. } & \text { Corps diplomatique } \\ \text { C.F.D.T. } & \text { Confédération française et démocratique du travail } \\ \text { C.G.T. } & \text { Confédération générale du travail } \\ \text { C.Q.F.D. } & \text { Ce qu'il fallait démontrer } \\ \text { C.-R.F. } & \text { Croix-Rouge Française } \\ \text { CAP } & \text { Certificat d'aptitude professionnelle } \\ \end{array}$




\begin{tabular}{|c|c|}
\hline CAPES & Certificat d'aptitude pédagogique pour l'enseignement secondaire \\
\hline CECA & Communauté européenne du charbon et de l'acier \\
\hline CEE & Communauté économique européenne (Marché Commun) \\
\hline CES & Collège d'enseignement secondaire \\
\hline Cf. & confer, comparez \\
\hline CGT-FO & Confédération générale du travail-Force ouvrière \\
\hline ch., chap. & chapitre \\
\hline Cie & Compagnie \\
\hline CNRS & Centre national de la recherche scientifique \\
\hline CRS & Compagnie républicaine de sécurité \\
\hline D.B. & Division blindée \\
\hline D.C.A. & Défense contre avions \\
\hline$d^{\circ}$ & dito, idem \\
\hline $\mathrm{E}$ & Est \\
\hline E.-M. & état-major \\
\hline E.V. & En ville \\
\hline EDF & Électricité de France \\
\hline ENA & École nationale d'administration \\
\hline etc. & et caetera, etcaetera \\
\hline EURATOM & Communauté européenne de l'énergie atomique \\
\hline év. & Évêque \\
\hline ex. & exemple \\
\hline F.M. & Franchise Militaire; Fréquence Modulée \\
\hline FEN & Fédération de l’Éducation nationale \\
\hline fév. & février \\
\hline fig. & figure; figuré \\
\hline Fo Ro Vo & Folio, recto, verso \\
\hline G.C. & Grand-croix \\
\hline G.D.F. & Gaz de France \\
\hline G.Q.G. & Grand Quartier général \\
\hline h & heure; habitants \\
\hline H.E.C. & Hautes études commerciales \\
\hline H.L.M. & Habitation à loyer modéré \\
\hline H.P., HP & cheval-vapeur \\
\hline H.T. & haute tension \\
\hline I.A.T.A. & Association de transport aérien international \\
\hline ibid. & ibidem \\
\hline id. & idem \\
\hline J.-C. & Jésus-Christ \\
\hline J.O. & Journal officiel \\
\hline jan. & janvier \\
\hline L. & leur \\
\hline larg. & largeur \\
\hline lat. & latitude \\
\hline long. & longitude, longueur \\
\hline M.L.F. & Mouvement de libération de la femme \\
\hline $\mathrm{m} /$ & mon, ma, mes \\
\hline $\min$. & minutes \\
\hline MRG & Mouvement des radicaux de gauche \\
\hline $\mathrm{n} / \mathrm{n} / \mathrm{N} / \mathrm{N} /$ & notre (correspondance commerciale) \\
\hline $\mathrm{N}$ & Nord \\
\hline N.B. & nota bene \\
\hline N.-D. & Notre-Dame \\
\hline N.D.L.R. & Note de la rédaction numéro \\
\hline N.-S. & Notre-Seigneur \\
\hline nbre. & novembre \\
\hline
\end{tabular}




\begin{tabular}{|c|c|}
\hline $\mathrm{n}^{\mathrm{o}}$, № & Numéro \\
\hline OEA & Organisation des états américains \\
\hline OMS & Organisation mondiale de la santé \\
\hline ONU & Organisation des Nations Unies \\
\hline op. cit & opere citato \\
\hline OPEP & Organisation des Pays Exportateurs de Pétrole \\
\hline ORTF & Office de la radio et de la télévision française \\
\hline OTAN & Organisation du traité de l'Atlantique-Nord \\
\hline OUA & Organisation de l'unité africaine \\
\hline P. et $\mathrm{T}$. & Postes et Télécommunications \\
\hline p. ex. & par exemple \\
\hline P.c.c. & Pour copie conforme \\
\hline P.-D. & Post-Data \\
\hline P.p.c. & Pour prendre congé \\
\hline P.Pon. & Par procuration \\
\hline P.-S. & Post-scriptum \\
\hline $\mathrm{PC}$ & Parti communiste; poste de commandement \\
\hline pp. & pages \\
\hline Préf. & Préfecture \\
\hline PS & Parti socialiste \\
\hline PTT & Postes, télégraphes et téléphones \\
\hline Q.G. & Quartier général \\
\hline q.q. & quelque \\
\hline R.S.V.P. & Répondez s’il vous plaît \\
\hline RATP & Régie autonome des transports parisiens \\
\hline RER & Réseau express régional \\
\hline $\mathrm{RF}$ & République française \\
\hline $\mathrm{RN}$ & Route nationale \\
\hline RPR & Rassemblement pour la République \\
\hline RTF & Radiodiffusion-télévision française \\
\hline S.D.N. & Société des Nations \\
\hline S.G.D.G., S.g.d.g. & sans garantie du gouvernement \\
\hline S.R. & Service de renseignements \\
\hline s.v.p. & s'il vous plaît \\
\hline SNCF & Société nationale des chemins de fer \\
\hline T.E.E. & Trans-Europe-Express \\
\hline T.N.P. & Théâtre national populaire \\
\hline T.S.F. & Télégraphie, téléphonie sans fil \\
\hline T.s.v.p. & Tournez s'il vous plaît \\
\hline Tél. & Téléphone \\
\hline Télg. & Télégramme \\
\hline TV & Télévision \\
\hline UDF & Union pour la Démocratie française \\
\hline UNEF & Union nationale des étudiants de France \\
\hline UNESCO & Organisation des Nations Unies pour l'éducation, les sciences et la culture \\
\hline UTA & Union des transports aériens \\
\hline V. & Votre; Voyez \\
\hline var. & variante \\
\hline $\mathrm{X}$. & École polytechnique \\
\hline
\end{tabular}


Càrrecs i tractament protocolari

$\begin{array}{ll}\text { A. } & \text { Altesse } \\ \text { A.I. } & \text { Altesse Impériale } \\ \text { A.R. } & \text { Altesse Royale } \\ \text { arch. } & \text { Archevêque } \\ \text { Cte } & \text { Comte } \\ \text { Ctesse } & \text { Comtesse } \\ \text { D. } & \text { Dom } \\ \text { Dr. } & \text { Docteur } \\ \text { E., Em. } & \text { Éminence } \\ \text { Fr. Frs. } & \text { Frère, Frères } \\ \text { LL.AA. } & \text { Leurs Altesses } \\ \text { LL.EE. } & \text { Leurs Éminences } \\ \text { LL.MM. } & \text { Leurs Majestés } \\ \text { M., Mr. } & \text { Monsieur } \\ \text { Me } & \text { Maître (en droit) } \\ \text { Mesd. } & \text { Mesdames } \\ \text { Mgr } & \text { Monseigneur } \\ \text { Mlle., M } & \text { Mademoiselle } \\ \text { Mlles. } & \text { Mesdemoiselles } \\ \text { MM., Mrs. } & \text { Messieurs } \\ \text { Mme., Mme } & \text { Madame } \\ \text { P. } & \text { Père (religieux) } \\ \text { R.P. } & \text { Révérend Père } \\ \text { S., St., Ste. } & \text { Saint, Sainte } \\ \text { S.A. } & \text { Son Altesse } \\ \text { S.E. } & \text { Son Excellence (ministre, embassadeur) } \\ \text { S.Em. } & \text { Son Éminence } \\ \text { S.Exc. } & \text { Son Excellence (évêque) } \\ \text { S.G. } & \text { Sa Grandeur } \\ \text { S.M. } & \text { Sa Majesté } \\ \text { S.S. } & \text { Sa Sainteté; Sécurité Sociale } \\ \text { SS. } & \text { Saints } \\ \text { Ve, Vve } & \text { Veuve } \\ & \end{array}$

\section{Banca, comerç, comptabilitat}

$\begin{array}{ll}\text { A. } & \text { avoir } \\ \text { A.P. } & \text { à protester } \\ \text { A.S.P. } & \text { accepté sous protêt } \\ \text { Act. } & \text { action } \\ \text { Acte. } & \text { acompte } \\ \text { Auj. } & \text { aujourd'hui } \\ \text { B.N.P. } & \text { Banque Nationale de Paris } \\ \text { B.P.F. } & \text { bon pour francs } \\ \text { Beau } & \text { bordereau } \\ \text { Brt. } & \text { brut } \\ \text { Bt. } & \text { billet } \\ \text { C. } & \text { colis } \\ \text { C.A.F. } & \text { coût, assurance, fret } \\ \text { C.C., c/c } & \text { compte courant } \\ \text { C.C.P. } & \text { comptes chèques postaux } \\ \text { C.O. } & \text { compte ouvert } \\ \text { C.P. } & \text { colis postal }\end{array}$


C/ caisse; compte; contre

$\mathrm{C} /$ Rembt. contre remboursement

Cap. capital

Cde. commande

Ces centimes

Cge. courtage

Cie compagnie

CNE Caisse Nationale d'Épargne

Com. commission

Compt. comptant

Ct. courant

Cte. compte

D., Dt. droit

Div. dividende

E. à $\mathrm{P}$. effets à payer

E. à R. effets à recevoir

Escte. escompte

Expon. expédition

f. à b. franco à bord

F., Frs. francs

Fcant. fabricant

Fco franco

Fre. facture

G.V. grande vitesse

L/C leur compte

M/Bt. mon billet

$\mathrm{M} / \mathrm{C} \quad$ mon compte

$\mathrm{M} /$ fact. ma facture

M/M/ moi-même

$\mathrm{M} / \mathrm{O} \quad$ mon ordre

Mge magasinage

Mt. mandat

N/M nous-mêmes

Négt. négociant

Nom. nominatif

$\mathrm{O} / \quad$ ordre

Obl., Oblig. obligation

P. et P. profits et pertes

P.D. port dû

P.P. port payé

P.V. petite vitesse

PDG Président-Directeur général

PME Petites et moyennes entreprises

PNB Produit National Brut

Port. porteur

R.C. registre de commerce

R.S.V.P. Répondez, s'il vous plaît

Règl. règlement

S.A. Société Anonyme

S.A.R.L. Société à responsabilité limité

S.E. ou O. sauf erreur ou omission

SIMCA Société industrielle de mécanique et de Carrosserie

SOFRES Société française d'études statistiques

$\mathrm{S}^{\text {té } \quad \text { Société }}$

T. tare

T.V.A. Taxe sur la valeur ajoutée 
$\begin{array}{ll}\text { Tte. } & \text { traite } \\ \text { v. / v/ } & \text { votre (correspondance commerciale) } \\ \text { V/v. } & \text { votre ville }\end{array}$

Mesures i quantitats

$\begin{array}{ll}\% & \text { pour cent } \\ \% \text { o } & \text { pour mille } \\ \mathrm{a} . & \text { are } \\ \mathrm{B} . & \text { balle } \\ \mathrm{C} . \mathrm{V} . & \text { cheval vapeur (fiscal) } \\ \mathrm{C} / \mathrm{m} & \text { centimètre } \\ \mathrm{dz} & \text { douzaine } \\ \mathrm{gr} & \text { gramme; Grosse } \\ \mathrm{H} l . & \text { hectolitre } \\ \mathrm{kg}, \mathrm{kil} & \text { kilogramme } \\ \mathrm{km} & \text { kilomètre } \\ \mathrm{kW} & \text { kilowatt } \\ \mathrm{l} & \text { litre } \\ \mathrm{m} & \text { mètre } \\ \mathrm{m} / \mathrm{m} & \text { millimètre } \\ \mathrm{m}^{2} & \text { mètre carré } \\ \mathrm{m}^{3} & \text { mètre cube } \\ \mathrm{st} . & \text { stère } \\ \mathrm{tr} / \mathrm{s} & \text { tours par seconde }\end{array}$

\section{Algunes abreviatures, sigles i acrònims catalans}

\section{Temes diversos}

$\begin{array}{ll}\text { A } & \text { amperi } \\ \text { a } & \text { arrova } \\ \text { A. C. } & \text { any de Crist } \\ \text { aC } & \text { abans de Crist } \\ \text { a/ } & \text { a l'atenció de } \\ \text { AA. } & \text { autors } \\ \text { adm. } & \text { administració } \\ \text { art. } & \text { article } \\ \text { BOE } & \text { Butlletí Oficial de l'Estat } \\ \text { bl. } & \text { bloc } \\ \text { c/c } & \text { compte corrent } \\ \text { cap. } & \text { capítol } \\ \text { CC } & \text { Cos Consular } \\ \text { cf. } & \text { confer, confronteu } \\ \text { Cia. } & \text { companyia } \\ \text { dC } & \text { després de Crist } \\ \text { dta. } & \text { dreta } \\ \text { dupl. } & \text { duplicat/da } \\ \text { E } & \text { est (Orient) } \\ \text { E. M. } & \text { Estat Major } \\ \text { ENE } & \text { est-nord-est } \\ \text { ESE } & \text { est-sud-est } \\ \text { esq. } & \text { esquerre/a }\end{array}$




\begin{tabular}{|c|c|}
\hline etc. & etcètera \\
\hline EUA & Estats Units d'Amèrica \\
\hline $\mathrm{F}$ & foli \\
\hline $\mathrm{FC}$ & ferrocarril \\
\hline FD & franqueig a destinació \\
\hline fig. & figura \\
\hline GC & Guàrdia Civil \\
\hline GP & gir postal \\
\hline gral. & general \\
\hline g.t. & gir telegràfic \\
\hline GU & Guàrdia Urbana \\
\hline $\mathrm{h}$ & hora \\
\hline ib., ibíd. & ibídem \\
\hline íd. & ídem \\
\hline imp. & import \\
\hline impr. & impremta \\
\hline impt. & impost \\
\hline J. C. & Jesucrist \\
\hline n. de la r. & nota de la redacció \\
\hline $\mathrm{N}$ & nord \\
\hline n., núm. & número \\
\hline NB, n. b. & nota bene \\
\hline $\mathrm{NE}$ & nord-est \\
\hline NNE & nord-nord-est \\
\hline NNO & nord-nord-oest \\
\hline NO & nord-oest \\
\hline $\mathrm{O}$ & oest \\
\hline OIT & Organització Internacional del Treball \\
\hline $\mathrm{OM}$ & ordre ministerial \\
\hline ONO & oest-nord-oest \\
\hline ONU & Organització de les Nacions Unides \\
\hline OP & ordre de pagament \\
\hline OSO & oest-sud-oest \\
\hline OTAN & Organització del Tractat de l'Atlàntic Nord \\
\hline p.p. & per poder \\
\hline p., pàg. & pàgina \\
\hline p.d. & postdata \\
\hline $\mathrm{s}$ & segon \\
\hline $\mathrm{S}$ & sud \\
\hline SA, s. a. & societat anònima \\
\hline SC, s. en c. & societat en comandita \\
\hline $\mathrm{SE}$ & sud-est \\
\hline secr. & secretaria \\
\hline seg. & següent \\
\hline SL, s. 1. & societat limitada \\
\hline $\mathrm{SO}$ & sud-oest \\
\hline SSE & sud-sud-oest \\
\hline tel. & telèfon \\
\hline tit. & titular \\
\hline TV & televisió \\
\hline v. gr. & verbi gratia, verbigràcia \\
\hline v. i p. & vist i plau \\
\hline v., veg., vid. & vegeu \\
\hline vol. & volum \\
\hline $\mathrm{W}$ & watt \\
\hline $\mathrm{x}$. & xec \\
\hline Z. & zona \\
\hline
\end{tabular}




\section{Càrrecs i tractament protocolari}

\begin{tabular}{|c|c|}
\hline (a) & àlies \\
\hline A. & Altesa \\
\hline AA. & Alteses \\
\hline alc. & alcalde, alcadessa \\
\hline cf. & confessor \\
\hline Dr., Dra. & Doctor, doctora \\
\hline E. & Excel·lència \\
\hline Emm. i Rvdm Sr. & Eminentíssim i Reverendíssim Sr. \\
\hline Exc. Sr. & Excel·lent Senyor \\
\hline Exc. Sra. & Excel·lent Senyora \\
\hline Excm. Sr. & Excel·lentíssim Senyor \\
\hline $\begin{array}{l}\text { Excma. Sra. } \\
\text { fr. }\end{array}$ & $\begin{array}{l}\text { Excel·lentíssima Senyora } \\
\text { fra }\end{array}$ \\
\hline Hble. Sr. & Honorable Senyor \\
\hline Hble. Sra. & Honorable Senyora \\
\hline $\mathrm{Il} \cdot \mathrm{lm} . \mathrm{Sr}$. & Il·lustríssim Senyor \\
\hline $\mathrm{Il} \cdot \operatorname{lma}$. Sra. & Il·lustríssima Senyora \\
\hline Il·ltre. Sr. & Il·lustre Senyor \\
\hline Il-1tre. Sra. & Il·lustre Senyora \\
\hline 1lic. & llicenciat, llicenciada \\
\hline M. Exc. Sr. & Molt Excel·lent Senyor \\
\hline M. Exc. Sra. & Molt Excel·lent Senyora \\
\hline M. Il·ltre. Sr. & Molt Il·lustre Senyor \\
\hline M. Il·ltre. Sra. & Molt Il·lustre Senyora \\
\hline M. & Mare (religiosa); Majestat \\
\hline Mgfc. Sr. & Magnífic Senyor \\
\hline Mgfca. Sra. & Magnífica Senyora \\
\hline Mn. & mossèn \\
\hline Mons. & monsenyor \\
\hline $\mathrm{mr}$ & màrtir \\
\hline P., PP. & pare (religiós); pares \\
\hline Rvdm. P. & Reverendíssim Pare \\
\hline Rvdma. M. & Reverendíssima Mare \\
\hline S. R. M. & Sa Reial Majestat \\
\hline S. S. & Sa Santedat \\
\hline Sr., Srs. & senyor, senyors \\
\hline Sra., Sres. & senyora, senyores \\
\hline Srt., Srts. & senyoret, senyorets \\
\hline Srta., Srtes. & senyoreta, senyoretes \\
\hline SSm. & Santíssim \\
\hline Sta., St. & santa, sant \\
\hline
\end{tabular}

\section{Banca, comerç, comptabilitat}

$\begin{array}{ll}\text { a/c } & \text { a compte de } \\ \text { ben. } & \text { benefici } \\ \text { c. } & \text { canvi } \\ \text { c/c } & \text { compte corrent } \\ \text { com. } & \text { comissió } \\ \text { ct. } & \text { cèntim } \\ \text { cte. } & \text { compte } \\ \text { d/d } & \text { dies data }\end{array}$




\begin{tabular}{|c|c|}
\hline dèf. & dèficit \\
\hline desp. & despesa \\
\hline doc. & document \\
\hline $\mathrm{d} / \mathrm{v}$ & dies vista \\
\hline ef. & efectiu \\
\hline $\mathrm{e} / \mathrm{c}$ & efecte a cobrar \\
\hline $\mathrm{e} / \mathrm{p}$ & efecte a pagar \\
\hline euro & $€$, EUR \\
\hline f/ & a favor (de) \\
\hline $\mathrm{f} / \mathrm{n}$ & a favor nostre \\
\hline$f / s$ & a favor seu \\
\hline$f / v$ & a favor vostre \\
\hline gar. & garantia \\
\hline h. & haver \\
\hline ien & $\mathrm{Y}$ \\
\hline inf. & informe \\
\hline liquid. & liquidació \\
\hline merc. & mercantil \\
\hline mín. & mínim/a \\
\hline $\mathrm{m} /$ fra. & la meua factura \\
\hline $\mathrm{m} / \mathrm{c}$ & al meu càrrec \\
\hline $\mathrm{m} / \mathrm{cte}$ & al meu compte \\
\hline $\mathrm{m} / \mathrm{t}$ & el meu taló \\
\hline $\mathrm{m} / \mathrm{x}$ & el meu xec \\
\hline $\mathrm{o} /$ & a l'ordre de \\
\hline $\mathrm{o} / \mathrm{p}$ & ordre de pagament \\
\hline p. d. & per delegació \\
\hline p. i. & pagament immediat \\
\hline p. o. & per ordre de \\
\hline $\begin{array}{l}\text { ppda., ppt. } \\
\text { pvt. }\end{array}$ & $\begin{array}{l}\text { proppassada, propassat } \\
\text { propvinent }\end{array}$ \\
\hline $\mathrm{p} /$ & pagaré \\
\hline pta., ptes. & pesseta, pessetes \\
\hline RBL & ruble \\
\hline s. d. & sense data \\
\hline sign. & signatura \\
\hline succ. & successor, sucessora \\
\hline t. & tarifa \\
\hline tripl. & triplicat \\
\hline u. & unitat \\
\hline $\mathrm{v} /$ & valor \\
\hline venc. & venciment \\
\hline vnt. & vinent \\
\hline $\mathrm{v} / \mathrm{c}$ & al vostre càrrec \\
\hline v/cte. & al vostre compte \\
\hline
\end{tabular}

\section{Mesures i quantitats}

$\begin{array}{ll}\mathrm{a} & \text { àrea } \\ \mathrm{C} . \mathrm{V} . & \text { cavall de vapor } \\ \mathrm{cg} & \text { centigram } \\ \mathrm{cl}, \mathrm{cL} & \text { centilitre } \\ \mathrm{cm} & \text { centímetre } \\ \mathrm{dg} & \text { decigram }\end{array}$




$\begin{array}{ll}\mathrm{Dg} & \text { decagram } \\ \mathrm{Dl} & \text { decalitre } \\ \mathrm{dl} & \text { decilitre } \\ \mathrm{Dm} & \text { decàmetre } \\ \mathrm{dm} & \text { decímetre } \\ \mathrm{g} & \text { gram } \\ \mathrm{ha} & \text { hectàrea } \\ \mathrm{hg} & \text { hectogram } \\ \mathrm{hl} & \text { hectolitre } \\ \mathrm{hm} & \text { hectòmetre } \\ \mathrm{kg} & \text { quilogram } \\ \mathrm{kl} & \text { quilolitre } \\ \mathrm{km} & \text { quilòmetre } \\ \mathrm{kW} & \text { quilowatt } \\ \mathrm{l} & \text { litre } \\ \mathrm{m} & \text { metre } \\ \mathrm{mg} & \text { mil·ligram } \\ \mathrm{mil} \cdot 1 . & \text { mil·lèsim/a } \\ \mathrm{Mm} & \text { miriàmetre } \\ \mathrm{rpm} & \text { revolucions per minut }\end{array}$




\section{Capítol II. \\ Selecció de textos per a traduir en francès-català}

Aquest capítol s'ha reservat per a disposar d'un elenc de textos autèntics que ja s'han utilitzat i provat en classe de traducció francès-català. L'objectiu últim és que servisquen d'ajuda a l'alumnat, però especialment al professorat, que de vegades inverteix molt de temps en localitzar textos profitosos per a les classes quotidianes. Aquesta selecció es pot fer servir com es considere convenient: localitzar la procedència dels textos, classificar-los segons el nivell de dificultat ( $\mathrm{F}=$ fàcil, $\mathrm{M}=$ mitjà, $\mathrm{D}=$ difícil), classificar-los segons els objectius d'aprenentatge, realitzar traduccions autònomes i compartir correccions posteriors amb companys, proposar-les al professorat de traducció, simular traduccions professionals amb facturació inclosa... En tot cas, cal recordar que els textos quasi mai són innocents, és a dir, que darrere d'una possible aparença d'assequibilitat poden amagar-se multitud de dificultats que han estat anteriorment localitzades pel «corrector» (el professorat) amb la finalitat de comprovar el grau de preparació de l'aprenent de traductor en les destreses necessàries per a esdevenir un autèntic professional de la traducció.

S'han escollit quinze textos, que corresponen a altres tantes setmanes lectives (aproximadament un semestre de classe). El títol de cada apartat exhibeix en certa manera les previsibles dificultats que s'han de considerar en la traducció, però no seran en absolut les úniques. Per a la presentació dels textos s'han tingut en compte diversos factors, com ara la llargària, el nivell de dificultat, els procediments o tècniques que s'han de seguir, etc. Els cinc primers textos s'acompanyen amb indicacions en notes al peu referides a l'encàrrec de traducció o amb advertiments sobre els problemes que s'han de resoldre; els textos centrals (del 6 al 10) porten la marca del subratllat per alertar o focalitzar sobre les qüestions més difícils; els cinc textos finals no donen cap pista de traducció i són el «termòmetre» de la competència traductora de cada estudiant. 


\subsection{L'extracció de nocions clau}

Les màximes o sentències curtes obliguen, a causa del seu missatge moralitzador concentrat, a extraure'n les nocions clau, sense les quals és impossible copsar-ne el sentit. Abans de traduir les frases cal anotar les nocions clau a banda, i explicitar-ne el sentit sense tenir en compte la forma que prendran finalment.

\section{(Text 1, 162 paraules)}

\section{Des bonbons et des maximes (Baci Perugina) ${ }^{1}$}

L'amour qui économise n'est jamais le véritable amour. (Balzac)

L'on est seul avec ce qu'on aime. (Novalis) ${ }^{2}$

De l'amour nous voulons jouir : sans lui nous ne saurions ${ }^{3}$ vivre. (E. Schikaneder)

Nous étions ensemble, le reste du temps je l'ai oublié. (Walt Withman)

La beauté provoque les larrons bien plus que l'or. (Shakespeare)

Mon ami, ne pensons pas à demain, cueillons ensemble cet instant de vie qui passe. (Omar Khayyam)

Nous ne pouvons parler franchement de nos défauts qu'à ceux qui reconnaissent nos qualités. (André Maurois) ${ }^{4}$

Ami, vole au secours de ma confiance ! (Hermann Melville)

Seul un scrutateur désintéressé peut voir clair dans le cœur d'une femme. (E. De Amicis)

Le cœur a ses raisons que la raison ne connaît point. (B. Pascal)

Ne vois-tu pas, Diable, que tu es belle comme un Ange? (G. Leopardi)

On a beau ne point se soucier des hommes, on a toujours besoin d'un ami. (Proverbio Cinese $)^{5}$

${ }^{1}$ Marca italiana que aprofita l'interior de cada embolcall per a imprimir una màxima.

${ }^{2}$ Atenció a l'ús impersonal del pronom «on».

${ }^{3}$ El verb «savoir» té una traducció especial quan es conjuga en temps condicional.

${ }^{4}$ És convenient repassar l'ús de la construcció restrictiva «ne... que» i les diverses traduccions que té.

${ }^{5}$ La complicació d'aquesta frase rau en la combinació «avoir beau» + «ne point», que obliga a un exercici de comprensió acurat. 


\subsection{La captació de les pressuposicions}

Una de les obligacions de tot traductor és conèixer les pressuposicions implícites de la cultura de la llengua que tradueix, és a dir, els sabers històrics, polítics, socials, religiosos, artístics, literaris o etnològics que els parlants d'una comunitat comparteixen mitjançant una cultura social, de llengua o de masses. En aquest text es lloen les qualitats d'un producte del camp que sembla ocupar un lloc de privilegi en la cuina francesa.

(Text 2, 229 paraules)

\section{Tout frais, tout près ${ }^{1}$}

Elle fête ses dix ans cette année. Elle a une chair ferme et un délicieux petit goût de beurre. Elle se sert en robe de champs, ${ }^{2}$ rôtie ou à la vapeur. Elle accompagne fort bien viandes, poissons ou fromages et se déguste volontiers accompagnée d'une salade croquante. ${ }^{3}$ Amandine est un délicieux tubercule, peu gourmand en engrais, ${ }^{4}$ cultivé en cycle court dans un sol particulièrement bien soigné.

Chez Jacky Cretegny, à Allens en pays vaudois, ${ }^{5}$ les champs sont travaillés spécialement pour accueillir Amandine dans les meilleures conditions : la terre est allégée de tous ses cailloux, qui disparaissent en profondeur pour laisser en surface un terreau ultraléger dans lequel seront logées ${ }^{6}$ les pommes de terre. Entre fins mars et fin avril, les plantations vont bon train. Trois semaines avant la récolte, on broie les fanes et l'on stoppe la végétation aérienne. Amandine peaufine ${ }^{7}$ alors sous terre ses saveurs caractéristiques. Les récoltes ont lieu de juillet à fin septembre.

Jacky Cretegny livre ses pommes de terre, triées selon leur calibre, à un centre d'empaquetage, d'où elles sont ensuite distribuées à destination des différentes centrales Migros. En magasin, on peut les acheter jusqu'en février. Il faudra ensuite patienter quatre mois avant de les retrouver sur les étalages. Elles méritent une place de choix dans nos menus, surtout en 2008, décrété année internationale de la pomme de terre !

${ }^{1}$ El títol traduït ha de recollir la idiomaticitat de l'original, fins i tot la rima.

${ }^{2}$ Metaforització que cal respectar sense que traspue massa rusticitat.

${ }^{3}$ Potser l'adjectiu «croquante» no és habitual en català per a aquest tipus de menjar, però caldrà inventar-lo per a aquest context.

${ }^{4}$ L'expressió «peu gourmand en engrais» mereix ser traduïda amb cert afecte, ja que combina el lèxic culinari amb l'agrari.

${ }^{5}$ «Pays» pot ser un fals amic si es tradueix literalment; «vaudois» remet a un topònim que s'haurà d'explicitar si no existeix el gentilici corresponent en català.

${ }^{6}$ L'estil particular del text opta per «logées» en lloc de «plantées», la qual cosa denota gran delicadesa en la tria de vocabulari.

${ }^{7}$ Atenció al verb transitiu «peaufiner», que té una aparença de composició entre dos elements. 


\subsection{La superació de les estructures}

La proposta traductora que es fa en l'exercici següent consisteix a canalitzar de forma diferent les idees i a rebutjar les estructures originals, però de manera que l'assimilitud de formes no implique una assimilitud de sentits. El traductor s'ha de posar en la pell d'un periodista radiofònic que prepara per escrit la crònica sobre un cantant de moda, que ha de connectar amb el llenguatge propi del gènere $i \mathrm{amb}$ la joventut dels seguidors.

\section{(Text 3, 253 paraules)}

\section{Le concert très sexe de Sébastien Tellier}

Hot. A 33 ans et avec seulement trois albums à son actif, Sébastien Tellier figure déjà au panthéon ${ }^{1}$ des génies de la chanson française.

C'est en 2001 que $^{2}$ le public découvre le célèbre barbu avec «L'incroyable vérité». Grand fan de ce premier essai, Air, l'un des groupes les plus tendances du moment, décide alors de faire jouer ${ }^{3}$ Sébastien Tellier en première partie de sa gigantesque tournée mondiale.

Trois ans plus tard, le Parisien est de retour dans les bacs avec «Politics». Cet album, dont ${ }^{4}$ la défense des peuples opprimés est le fil conducteur, lui fera connaître le succès auprès du grand public français et anglais avec son morceau «La ritournelle».

Considéré dès lors comme une icône de l'electro-pop française, Tellier tourne avec Moby, remixe Eurythmics, signe la BO du film «Narco» et collabore avec les plus grands musiciens (Tony Allen, Pamelia Kurstin, Simon Dalmais...). De toutes ses expériences en résulte «Sexuallity». Un chef d'œuvre plus electro que pop sorti cette année et sur lequel le dandy poète parle de $\mathrm{cul}^{5}$ durant une heure avec humour, romantisme, sensualité et sauvagerie.

C'est essentiellement ce $3^{\mathrm{e}}$ album que l'artiste nous fera vivre au D! Club durant un concert où l'émotion sera mise. ${ }^{6}$ Car si Sébastien Tellier est un compositeur dont le talent n'a plus à être reconnu, ${ }^{7}$ il est surtout une bête de scène capable de tous les excès. Déjantées, alcoolisées, fumeuses et délurées, les performances live ${ }^{8}$ de cet artiste sont, tout simplement, de grands moments de folie.

${ }^{1} \mathrm{~S}$ 'ha de valorar l'elecció del lèxic, per si de cas resulta massa fúnebre en català. «Panthéon» remet a un monument concret de París.

${ }^{2}$ La fórmula típica d'insistència «c'est... que» només s'ha de recollir en les traduccions quan realment hi ha intenció d'insistir sobre alguna cosa.

${ }^{3}$ L'expressió «faire jouer» s'ha de processar evitant la literalitat, com moltes altres expressions del tipus «faire + infinitif».

${ }^{4}$ El relatiu «dont» no sempre s'ha de solucionar amb «del qual / de la qual» i les altres variants; en aquest cas s'han de superar les estructures.

${ }^{5}$ Cal valorar i estudiar amb cura l'expressió «parle de cul»; potser ajudarà molt consultar un estudiant Erasmus francòfon.

${ }^{6}$ La veu passiva és més habitual en francès que en català.

${ }^{7}$ L'obligació «avoir à + infinitif» (equivalent a «haver de + infinitiu») es combina ací amb «ne... plus», que indica una cosa superada.

${ }^{8}$ La composició neològica «performances live» necessita un tractament documentat, potser mitjançant textos paral-lels localitzables a Internet. 


\subsection{Els neologismes}

En traducció, el tractament que s'ha de donar als neologismes és molt variat i depèn de les opinions teòriques dels investigadors. Tanmateix, a banda de recórrer a la Neoloteca del TERMCAT, es poden seguir les instruccions de la taula d'alerta següent (Verdegal, 2003: 8), en la qual, després d'anotar el lexema original (TLO) i la proposta personal de traducció (TLM), s'haurà de respondre a un qüestionari que guiarà les decisions finals.

\begin{tabular}{|c|c|c|c|}
\hline TLO & TLM & Pregunta & Resposta \\
\hline & & N'existeix ja l'equivalent en català? & sí/no \\
\hline & & És necessària una nota aclaridora? & sí/no \\
\hline & & S'acomoda a les necessitats i les peculiaritats dels destinataris? & sí/no \\
\hline & & Hi ha conflicte entre allò polític i allò lingüístic? & sí/no \\
\hline & & S'hi han tingut en compte el context i la intenció? & sí/no \\
\hline & & Compleix els criteris d'acceptabilitat lingüística? & sí/no \\
\hline & & Compleix els criteris d'acceptabilitat terminològica? & sí/no \\
\hline & & Denomina un concepte estable? & sí/no \\
\hline & & És transparent i pot memoritzar-se sense dificultat? & sí/no \\
\hline & & Permet formar sèries derivatives? & sí/no \\
\hline & & Etc. & sí/no \\
\hline
\end{tabular}

L'objectiu principal d'aquest exercici és proposar diverses solucions per al neologisme que presideix el text i justificar-ne la traducció final.

(Text 4, 334 paraules)

\section{Phénomène Book Crossing ${ }^{1}$}

Tout à commencé le soir, où aprés une soirée mouvementée, nous avons atteri dans un parc de Lille, ${ }^{2}$ le jardin de la Treille, et que par le fruit du hasard, mon regard est tombé sur un livre, posé contre le mur d'une tour. "La prophétie des Andes".

A l'intérieur de ce bouquin, un petit mot: "je suis un livre gratuit! Prenez moi, lisez moi, libérez moi ! Et merci pour le voyage !", et une étiquette "BookCroosing" avec un numéro. Peu de temps aprés, en écoutant la radio sur le moov', j'ai appris que "bookcrossing" possedait un site.

BookCrossing est un mouvement bibliophile international, depuis avril 2001 dont le principe est de faire circuler par le moyen du hasard les livres que vous avez aimés et que vous souhaitez partagés. Il compte 150000 membres et 500000 livres en circulation.

Pour y participer, il suffit de s'inscrire sur le site bookcrossing.com, et d'y enregistrer le livre que vous souhaitez faire voyager. Vous aurez alors accès au code BCID (boock crossing identity), et aprés avoir imprimé une des étiquettes disponibles sur le site, et y inscrire le code, vous n'aurez alors plus qu'à laisser votre livre n'importe où, dans un lieu public comme un parc, un café, ou même une rue ! Vous pouvez même indiquez l'endroit et le jour où vous l'avez déposé pour permettre à d'autre Book Crosser de votre ville de le chercher. Si quelqu'un le trouve et se manifeste sur le site, vous serez prévenu par mail. Vous trouverez aussi sur le site, une liste des book crossers francophones, et pourrez partager avec eux des opinions sur divers bouquins sur le forum. 
Si vous trouvez un livre comme je l'ai fait, vous pouvez l'enregistrer gratuitement et simplement sur le site dans la rubrique "Qu'est ce que le Book Crossing ?", afin de créer un lien entre les personnes qui ont lu ce livre auparavant.

Alors, n’hésitez pas, et filez faire un tour sur le site !!!!

${ }^{1}$ La qualitat dels textos procedents d'Internet no està garantida; per això hi apareixen diverses grafies per al fenomen que es descriu (Book Crossing / BookCrossing / bookcrossing / book crossing). També hi ha altres faltes d'ortografia, cinc en concret, que cal localitzar i "simular" o "dissimular" en la traducció (segons la consigna del professor).

${ }^{2}$ Topònim de ciutat francesa. Té una traducció encunyada?

${ }^{3}$ Cal aplicar la regla habitual per a la traducció de títols de llibres.

\title{
2.5. L'estil
}

Cada persona té una manera particular d'expressar les seues idees per escrit, és a dir, un estil propi que l'identifica. L'estil pot ser inconscient, però quan es pretén produir un efecte determinat en el lector potencial esdevé conscient i motivat. Aleshores entren en joc multitud de recursos creatius: les figures estilístiques, els idiomatismes, les locucions... La proposta de traducció que segueix busca sensibilitzar sobre les possibilitats creatives que es presenten a un traductor, i incita a introduir-hi fórmules riques en imatges corresponents a les del text en francès.

\section{(Text 5, 351 paraules)}

\begin{abstract}
Moi, rat de labo accro au tabac
Je me présente : rat de laboratoire, à l'université de Bordeaux II. No 19 . C'est écrit au marqueur sur ma queue. Logé, nourri, blanchi. Avec la sécurité de l'emploi. Une existence paisible, en somme. ${ }^{1}$ Et pourtant, ${ }^{2}$ il suffit de vingt-quatre heures d'abstinence pour que je devienne nerveux. Je l'avoue : je suis accro à la nicotine. A chaque bruit de pas, signe annonciateur de ma séance de dope, je me précipite sur le grillage de l'animalerie.

L'objet de mon excitation est une cage étrange, dite d'activité. J'ai dû attendre d'être adulte, à 2 mois bien tassés, pour y avoir accès. Dès la première fois, j'ai été intrigué par le trou percé dans la paroi métallique, à hauteur de ma tête. J'y ai introduit mon museau. Divine surprise! J'ai reçu dans la seconde qui a suivi un shoot de nicotine, ${ }^{3}$ via le fin tuyau implanté à vie dans ma veine jugulaire. ${ }^{4}$ Le secret de ce dispositif ? Avec mon museau, je coupe un rayon photoélectrique, signal immédiatement transmis à un micro-ordinateur. Comme je ne suis pas du genre à bouder mon plaisir, ${ }^{5} \mathrm{j}$ 'ai renouvelé l'expérience une vingtaine de fois ce jour-là. Et j'ai fait de même le reste de la semaine.
\end{abstract}

Le huitième jour, pourtant, j'ai cru m'évanouir. Il était 13 h $30 .{ }^{6}$ La nuit, contrôlée artificiellement par les chercheurs de l'Inserm, venait de tomber, comme d'habitude — dois-je rappeler que les rongeurs dorment le jour et s'activent dans l'obscurité ? Je reprends : cette nuit-là, je fourre donc machinalement mes moustaches dans l'orifice. Et là, rien ne se passe. Refusant de croire à l'irréparable, je recommence. Ouf ! Cette fois, je suis comblé. Pour un temps seulement. Car je devine déjà que l'équipe de chercheurs dirigée par Pier Vincenzo Piazza va désormais mettre ma motivation à l'épreuve. Et, en effet, plus le temps passe, plus le prix à payer pour obtenir ma dose est élevé. Le tarif montera jusqu'à 30 actions successives ! De quoi décourager le plus accro des rats. ${ }^{7}$ 
${ }^{1}$ L'estil telegràfic té una intenció determinada que cal mantenir.

${ }^{2}$ Tots els falsos amics són perillosos, però «pourtant» ho és especialment, perquè una traducció errònia implicaria una falta d'encadenament textual.

${ }^{3}$ Cal aprofitar les indicacions de l'apartat anterior sobre els neologismes.

${ }^{4}$ Heus ací un recurs expressiu propi de la medicina o de la infermeria.

${ }^{5}$ Aquesta frase es presta a múltiples reformulacions.

${ }^{6}$ Atenció a l'expressió numèrica de les hores en català.

${ }^{7}$ «De quoi + infinitif» obliga a certa exegesi, complementària a la consulta d'un diccionari.

\subsection{El grau d'implicació}

Segons l'encàrrec de traducció, segons el grau de compromís que es vol establir amb el text, segons el que es vol transmetre al lector, o també segons la distància existent entre el text original i el traduït, el traductor hi pot establir un grau d'implicació, posar filtres, adaptar certes referències, dixis de subjectivitat, afectives o connotacions de l'univers cultural del text original. És el que pot passar en el text següent.

(Text 6, 360 paraules)

\section{Histoire de France}

C'est à l'occasion de son cours d'histoire de France au collège américain de Paris que G. de Bertier s'est aperçu qu'il n'y avait pas d'ouvrage pratique correspondant aux besoins de grands étudiants ignorant presque tout, au départ, de l'histoire de France.

Pour bien remplir ce rôle pratique, il importe moins de faire connaître l'histoire telle qu'elle est appréhendée et écrite aujourd'hui, que l'histoire jadis enseignée, dont se sont nourris les créateurs des œuvres que l'on étudie, depuis Montaigne jusqu'à Malraux. L'histoire de France, pour eux, c'était Charlemagne, Saint Louis, Jeanne d'Arc, Bayard, Richelieu, Robespierre, Napoléon; c'était la croisade, la guerre de Cent Ans, la bataille de Marignan, la Saint-Barthélemy, la prise de la Bastille, la bataille de Waterloo, etc. Et non pas les variations du climat languedocien, le taux de fécondité des femmes de Meulan, la courbe d'évolution de la rente foncière. Pour comprendre les allusions historiques dont sont pleines les grandes œuvres de notre littérature, pour lire les tableaux qui remplissent nos musées, il faut savoir un peu d'histoire de France à la manière de nos aïeux.

L'auteur a donc cherché à apporter ce minimum de connaissances historiques indispensables à quiconque aborde la civilisation française sous ses divers aspects. Il a cherché à le faire sous une forme aussi dépouillée et aussi concise que possible sans cesser d'être lisible. Evitant tout effet de style, tout jeu d'esprit, tout vocabulaire insolite, toute allusion obscure. Evitant aussi tout ce qui relèverait d'un parti pris politique conscient ou d'une philosophie, mais sans s'interdire - ce qui eût été irréalisable - de laisser voir ses sympathies ou de formuler des jugements de valeur sur les hommes et leurs actions.

L'auteur pense, avec Henri-Irénée Marrou (De la connaissance historique), que l'histoire de la civilisation, pour être abordée avec fruit, «doit se projeter sur un réseau serré de noms, de dates, d'événements précis». C'est justement cette trame qu'il a voulu fournir.

G. de Bertier de Sauvigny, enseignant et historien-écrivain, est l'auteur de nombreux ouvrages, entre autres La Restauration (publié en 1955 et récemment réédité chez Flammarion), La Révolution de 1830 en France, Metternich et la France après le Congres de Vienne, etc. 


\subsection{Els argots}

Una de les nombroses possibilitats expressives que ofereix el llenguatge és l'argot, bé referit a un grup social, a una especialitat professional o a una activitat sectorial determinada. El text que cal traduir ara no pot considerar-se «xifrat», però sí que presenta certes dificultats.

\section{(Text 7, 383 paraules)}

\section{Perte sèche à Zaventem}

Mis en ligne le 13/04/2007

- Brussels Airport a essuyé une grève qui a paralysé les mouvements d'avion.

- Plus de 200 vols ont été annulés vendredi et 26000 voyageurs ont été pénalisés.

- Pour le gestionnaire du site, le manque à gagner se chiffre à plusieurs milliers d'euros.

En voilà un mouvement qui risque de peser sur les comptes 2007 de Brussels Airport company (BAC), la société gestionnaire de l'aéroport national. Brussels Airport a été paralysé vendredi par une action de grève déclenchée par les pompiers et une partie du personnel de sécurité. "Les pertes pour Brussels Airport sont impossibles à chiffrer pour l'instant, mais au-delà du manque à gagner sur le plan financier, l'image de l'aéroport prendra aussi un coup. L'impact est aussi important pour les compagnies aériennes", commente Jan Van der Cruysse, porte-parole de l'aéroport.

En effet, 201 vols partants et de nombreux vols de fret (vers un total de 200 destinations) ont été annulés au départ de l'aéroport national et environ 26000 voyageurs ont été confrontés à d'importants retards. Tout bénéfice pour les aéroports régionaux de Liège, de Charleroi ou encore d'Anvers qui ont volé au secours de leur grand frère pour accueillir sur leur tarmac les avions détournés de Zaventem. VLM a détourné sur Anvers cinq vols, mais Brussels Airlines a annulé pas moins de 30 vols et 40 de ces appareils ont été bloqués au sol. "Les passagers peuvent se faire rembourser ou réserver un vol à une autre date", a indiqué Geert Sciot, porte-parole de la compagnie aérienne, née de la fusion de SN Brussels Airlines et de Virgin Express.

Exigences disproportionnées

La perte financière pour $\mathrm{BAC}$ devrait se chiffrer à plusieurs milliers d'euros. Car la société gestionnaire n'a pas pu percevoir de taxes aéroportuaires en raison de la grève. La redevance pour l'utilisation des installations aéroportuaires par exemple s'élève à $22,44 €$ par passager (en cas de départ), 14,08€ (en cas de transfert) et 4,09€ (en cas de transit).

En faisant le calcul, on peut aisément imaginer la perte financière de l'aéroport suite à la grève. "La direction regrette que les syndicats aient utilisé le droit de grève pour revendiquer des exigences disproportionnées par rapport aux buts à atteindre", a déploré la société gestionnaire dans un communiqué. 


\subsection{Les oposicions i els contrastos}

De vegades, pel que fa a l'estil i el lèxic, els textos presenten de forma més o menys patent relacions argumentatives que serveixen per a contrastar parelles d'elements. Per tant, és obligació del traductor saber copsar els contrastos que aqueixes oposicions produeixen, a fi de traslladar-los al text final. En cas contrari, la traducció s'empobreix fins a convertir-se en anèmica.

(Text 8, 397 paraules)

\section{Toute nue, la reine Néfertiti bouleverse l'Egypte}

Le Caire

de notre correspondant

Les archéologues et intellectuels égyptiens sont dans tous leurs états depuis que le musée égyptien de Berlin a décidé de doter le célèbre buste de la reine Néfertiti d'un corps de femme nue. Le conservateur de ce musée, Dietrich Wildung-Schoske, a en effet commandité à deux artistes hongrois une statue en bronze dans laquelle viendrait se loger la tête

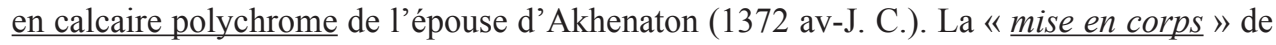
la pièce maîtresse du musé a été très médiatisée et les images publiées par la presse égyptienne, samedi 7 juin, ont provoqué un tollé.

Quand la reine est nue, ses sujets sont en colère ! Tellement en colère que le ministre égyptien de la culture, Farouk Hosni, réclame son retour immédiat à la mère patrie. Le ministère des affaires étrangères a été sommé de protester contre cet « affront à l'histoire égyptienne 》 et l'Unesco alertée de cette « atteinte à l'éthique scientifique ». Même si les autorités égyptiennes affirment que leurs préoccupations sont d'ordre égyptologique, il ne fait pas de doute que c'est la nudité toute nue qui fait jaser. Dans la vallée du Nil on n'accepte pas que l'épouse du chef de l'État - même si cela se passait il y a plus de trois mille ans - expose son corps au regard concupiscent du premier venu !

Les égyptologues du Caire se déchaînent contre le musée de Berlin. Son directeur est accusé, par les journaux, d'avoir voulu se venger personnellement de l'Egypte qui l'a interdit de fouilles après que des rapports policiers eurent évoqué ses éventuels liens avec des trafiquants d'antiquités. Et la presse rappelle «l'arnaque » qui a permis la sortie du chefd'œuvre d'Egypte.

C'était le 6 décembre 1912. La mission allemande fouillant le site de Tall el-Amarna, capitale éphémère d'Akhenaton, tomba sur l'atelier du " grand maître des sculpteurs de la cour » Tothmès. Découvrant le buste, les archéologues allemands « omirent» d'informer le service archéologique égyptien de l'importance de la découverte. La statue fut-elle maquillée ou cachée aux inspecteurs qui donnèrent leur accord pour le départ vers l'Allemagne? Mystère. Quand la statue fut enfin exposée au musée de Berlin en 1922, l'Egypte décida d'interdire aux archéologues allemands de fouiller en Egypte. L'histoire se répétera-t-elle à cause de Néfertiti toute nue? 


\subsection{L'organització textual}

L'ordre de les paraules està marcat habitualment per normes sintàctiques o d'ús en cada llengua. Tanmateix, uns elements tenen més mobilitat que d'altres, i això és utilitzat amb fins estilístics. Forma part de la tasca del traductor conèixer les subtils diferències entre l'organització textual del parell de llengües, cosa que haurà aconseguit $\mathrm{amb}$ intuïció lingüística adquirida per la pràctica. Però el traductor també ha d'esbrinar la tonalitat del text per traduir, que reflecteix l'actitud del redactor enfront d'allò que escriu; aquesta actitud pot ser neutra, tràgica, humorística, irònica, polèmica, etc.

\section{(Text 9, 438 paraules)}

\section{Le pourboire était en bois}

New York

De notre correspondant François MILLER

Le pourboire de 10.000 dollars (70.000 F) laissé à une serveuse d'un bar de Chicago n'était qu'un serment d'ivrogne. Le généreux client, un Britannique de 35 ans, a, en fait, laissé un chèque en bois et a reconnu qu'il avait agi sous l'emprise de l'alcool.

« J'ai trop bu et j'accusais le coup du décalage horaire », a expliqué à un journal britannique David Nicholas, un ingénieur en informatique, marié et père d'un enfant de 10 mois.

Pis encore, David Nicholas affirme qu'il ne se souvenait même pas de son escapade et du nom de la serveuse. Pourtant, Melanie Uczen, une jolie blonde de 23 ans, n'oubliera pas son aventure.

Lundi dernier, à 3 heures du matin, trois inconnus se font servir un thé glacé au Leg Room, le bar chic de Chicago où elle travaille. Elle explique qu'elle travaille dur pour payer ses études de psychologie. « Moi aussi, j'ai travaillé pour arriver où je suis », lui répond son client qui explique qu'il est un riche médecin et se trouve à Chicago pour ses affaires.

Au moment de payer l'addition ( 9 dollars seulement), surprise : le « médecin » brandit sa carte de crédit. « J'ai laissé un pourboire de 1.000 dollars la nuit dernière dans un restaurant. Cette fois, je veux laisser plus. Et vous méritez quelque chose... »

Passeport

Melanie Uczen n'en croit pas ses yeux lorsqu'elle voit inscrire la somme de 10.000 dollars. La direction, prudente, s'assure que la carte de crédit n'est pas volée, fait photocopier le passeport du généreux client et lui fait signer une décharge stipulant : « J'ai laissé 10.000 dollars de pourboire à Melanie Uczen. » Hélas ! Au moment d'empocher le compte, Melanie Uczen découvre que le compte n'est pas suffisamment apprivoisé et que la banque refuse de la payer. L'explication de David Nicholas : « Je suis quelqu'un de généreux et j'ai effectivement pu laisser un gros pourboire. C'est bien mon genre. Mais, malheureusement, je ne peux pas payer une telle somme. »

Melanie Uczen ne devrait pas, cependant, dire adieu à tous ses plans bâtis sur la comète. Son employeur s'est engagé à lui payer les 10.000 dollars si la promesse du Britannique n'est pas honorée. «Cette histoire nous a fait beaucoup de pub, reconnait Fred Hoffman, le patron de la compagnie qui possède le bar. Alors, pourquoi briser le rêve ? "

Mieux : le magazine Playboy aurait proposé à Melanie Uczen de poser pour une de ses éditions. Si elle accepte, David Nicholas pourra toujours au moins se rincer... l'œil. 


\subsection{L'argumentació}

A més de les competències semàntica i sociocultural, el traductor mobilitza una competència pragmaticoargumentativa que el capacita per a introduir-se en l'estructura argumentativa de la unitat textual i desxifrar-ne les intencions argumentatives, que de vegades no es discerneixen a simple vista.

\section{(Text 10, 484 paraules)}

\section{Boire avec modération dans le temps des Fêtes}

Lever son verre entre amis dans le temps des Fêtes est une tradition pour de nombreux Canadiens. Il faut toutefois être conscient que boire ou servir trop d'alcool peut causer des problèmes de santé et bien d'autres ennuis.

L'alcool est une drogue, un agent déprimant qui ralentit le système nerveux central. Plus vous buvez d'alcool, plus votre concentration, votre élocution, votre équilibre, votre vision, votre coordination et votre discernement s'en ressentent. Les effets de l'alcool peuvent aussi être augmentés par le stress du temps des Fêtes.

La quantité d'alcool que vous pouvez consommer avant d'en ressentir les effets dépend de nombreux facteurs : la quantité d'alcool que vous consommez habituellement; la vitesse à laquelle vous buvez; votre humeur; la force de votre corps; la quantité de nourriture que vous avez absorbée; vos expériences antérieures avec la consommation d'alcool; et votre sexe. Selon la Stratégie canadienne antidrogue, pour la plupart des adultes, une consommation modérée d'alcool correspond à au plus un verre par jour et au plus 7 verres par semaine. Le fait de consommer plus de 4 verres en une occasion ou plus de 14 verres par semaine est considéré comme un risque pour votre santé et votre sécurité.

Si vous buvez trop en une seule occasion, vous ressentirez les effets suivants : somnolence; étourdissement; manque de coordination; incapacité de penser et de juger clairement; et incapacité d'évaluer les distances et temps de réaction plus long.

Vous buvez trop si vous présentez l'un de ces symptômes : vous devez boire davantage pour ressentir le même effet euphorique; vous dépensez de plus en plus pour de l'alcool; vous manquez d'appétit et d'entrain, vous souffrez d'insomnie ou vous transpirez abondamment lorsque vous ne buvez pas; vous souffrez d'amnésie lorsque vous buvez ou vous ne vous rappelez pas avoir bu; ou vous souffrez de confusion et de pertes de mémoire.

L'abus d'alcool à long terme peut causer de nombreux problèmes de santé, notamment : maladies du foie; maladies du cœur; ulcères d'estomac; troubles des vaisseaux sanguins; dysfonction érectile chez les hommes; irrégularités menstruelles chez les femmes; et certains types de cancer.

Le fait de boire de l'alcool pendant la grossesse, même une quantité raisonnable, peut altérer le foetus et causer divers problèmes de santé connus sous le nom de troubles du spectre de l'alcoolisation foetale. Des études récentes portent à croire que la consommation d'alcool pendant la grossesse, même en très petites quantités, peut avoir des effets négatifs sur le développement du cerveau de l'enfant. En somme, il n'y a donc pas de bon moment ou de quantité raisonnable pour ce qui est de boire de l'alcool pendant la grossesse.

Des quelque 3000 décès causés par des collisions de véhicules automobiles, environ $40 \%$ sont attribuables à l'alcool. L'abus d'alcool peut également causer de sérieux ennuis professionnels, familiaux, financiers et juridiques, ce qui peut nuire à votre santé. 


\subsection{Les ambigüitats}

Una traducció no pot ser més ambigua que el text original. De vegades, però, una característica pròpia en pot ser la multiplicitat interpretativa; aleshores, el traductor té l'obligació de preservar-la fins a les últimes conseqüències, de manera que l'efecte produït en el lector virtual inicial s'acoste al que rep el lector final.

(Text 11, 588 paraules)

Dr. Franck MORGAN [Carta rebuda per correu brossa]

Cher Amie,

Il est de mon plaisir de vous écrire cette lettre indépendamment du fait que vous ne me connaissez pas. Cependant, j'ai eu votre contact dans ma recherche privée, d'une personne digne de confiance qui peut manipuler une transaction confidentielle de cette nature en ce qui concerne nos plans d'investissement dans l'immobilier. Bien que, je sache qu'une transaction de cette grandeur pourrait rendre n'importe qui appréhensif et inquiet, mais je vous assure que tout ira bien à la fin de celle-ci.

Je suis Dr. Franck MORGAN de la section apurant d'une banque ici à ABIDJAN, COTE D'IVOIRE. Avec le respect dû à votre rang, j'ai décidé de vous contacter sur une transaction qui sera très salutaire à tous les deux à la fin de celle-ci. Pendant notre recherche, mon département a trouvé une somme d'argent par hasard très énorme appartenant à une personne décédée, un Étranger qui est mort le 31 octobre 1999 dans un accident d'avion, et les fonds ont été dormants dans son compte à la banque sans n'importe quelle réclamation des fonds de la part de sa famille ou relation avant notre découverte de cette somme. Personnellement, deux de mes associés et moi avons maintenu cette information secrète pour permettre la mise en place des plans et des idées qui conduiront à l'exécution avec succès de la transaction. Le montant impliqué est (US\$11.5M) Onze millions cinq cent mille de dollars des Etats-Unis. Je crois que vous serez dévoué et capable pour soutenir des affaires d'une telle grandeur sans n'importe aucun problème.

En attendant, tous les arrangements pouvant vous permettre de réclamer les fonds en tant que véritables parents du défunt, afin d'obtenir l'approbation exigée pour le transfert de cet argent dans un compte étranger, ont été mis en place. Les directives et informations nécessaires vous seront transmises dès que vous indiquerez votre intérêt et bonne volonté à nous aider.

Je pouvais faire cette affaire tout seul, mais en raison de ma position dans ce pays, en tant que fonctionnaire nous ne sommes pas permis d'actionner un compte étranger et cela pourrait soulever par la suite un souci de mon côté pendant la période du transfert parce que je travaille à cette banque. C'est la raison réelle pour laquelle cela exige une deuxième partie. Celle-ci fera des réclamations à la banque en tant qu'un proche parent à l'Étranger décédé. Cette personne doit avoir également un compte étranger dans lequel l'argent pourra être transféré sur sa demande après toute vérification.

Je ne manquerai pas de vous informer que cette transaction ne comporte aucun risque. De ce côté je tiens à vous rassurer. Après conclusion de cette transaction, vous aurez droit à $20 \%$ de toute la somme comme récompense, et $5 \%$ sera mis de côté pour effectuer des dépenses qui peuvent surgir pendant la période du transfert tel que les factures etc., de téléphone, alors que $75 \%$ sera mes associés et moi.

S'Il VOUS PLAIT, JE VOUS DEMANDE DE GARDER CETTE AFFAIRE SECRETE PENDANT QUE NOUS SOMMES TOUJOURS EN SERVICE CAR NOUS PREVOYONS DE NOUS RETIRER DU SERVICE APRES QUE NOUS AYONS CONCLURE CETTE AFFAIRE AVEC VOUS.JE SURVEILLERAI LA SITUATION ENTIERE ICI A LA BANQUE JUSQU'A CE QUE VOUS CONFIRMIEZ QUE L'ARGENT EST DANS VOTRE COMPTE ET ME DEMANDIEZ DE DESCENDRE A VOTRE PAYS POUR LE PARTAGE DES FONDS SELON LE POURCENTAGE PRECEDEMMENT INDIQUE.

Nous allons investir plus dans votre pays ou n'importe quel autre pays que vous pouvez conseiller. Toute autre information nécessaire vous sera envoyée quand j'aurai de vos nouvelles.

Sincères salutations. 


\subsection{Els sobreentesos}

No es pot comprendre del tot un enunciat sense copsar el pes del que s'hi sobreentén. Els sobreentesos es caracteritzen precisament perquè necessiten un procés interpretatiu per part del traductor, que no serà possible si no té una qualitat fonamental: la perspicàcia.

(Text 12, 640 paraules)

\section{L'imprécateur}

Lorsque survinrent les évènements relatés ici, Rosserys \& Mitchell avait entrepris de construire des usines non point dans les pays assez riches pour acheter eux-mêmes les engins fabriqués et emballés sur leur sol, mais au contraire dans les pays pauvres et démunis de denrées pour la raison que les salaires payés aux ouvriers de ces pays étaient moins élevés qu'ailleurs.

Les gens qui à l'époque se pressaient sur le pavois, tant étaient subtiles leurs réflexions, étendues leurs connaissances, éprouvées leurs techniques, portaient haut leur superbe et leur rengorgement. Et aussi la philosophie que voici :

a) fabriquons et emballons chez nous des engins et vendons-les chez nous ;

b) maintenant, vendons nos engins à ceux de l'extérieur qui ont de l'argent pour les acheter ;

c) fabriquons et emballons sur place, toujours chez ceux qui ont de l'argent pour acheter ;

d) pourquoi ne pas fabriquer et emballer nos engins dans les pays pauvres, de façon à les obtenir moins chers?

e) à la réflexion, pourquoi ne pas fabriquer les vis de nos engins là où ils coûtent le moins cher, assembler le tout là où ça coûte le moins cher d'assembler, l'emballer tout là où ça coûte le moins cher d'emballer ?

f) et, finalement, pourquoi se limiter à la fabrication d'engins ? Avec tout l'argent qu'on gagne, pourquoi ne pas acheter tout ce qui est à vendre ? Pourquoi ne pas transformer notre industrie en gigantesque société de placement?

La sécheresse de ce processus masquait un altruisme remarquable. La construction d'usines et d'immeubles sur toute la surface du globe apportait du travail et de la nourriture aux peuples maigrement pourvus, accélérait leur marche vers le progrès et le bien-être. C'est pourquoi ces gens qui, en fabriquant, en emballant et en vendant, édifiaient le bonheur de l'humanité en vinrent à se demander à quoi pouvaient servir les assemblées politiques et les gouvernements. Voici ce que ces néo-patriciens, qui décidément avaient pénétré les secrets de l'âme humaine, répondirent : « Nous qui fabriquons, emballons et vendons, nous créons les richesses et nous en remettons une part importante aux institutions politiques, librement ou non élues, qui les redistribuent. Ces richesses, nous ne les voulons pas les repartir nousmêmes, car nous serions juge et partie. Ainsi, le monde, après tant de soubresauts et de déchirements millénaires, a enfin trouvé sa voie : fabriquer, emballer, vendre, distribuer le produit de la vente. En somme, de même qu'en des temps préhistoriques on avait séparé les Églises et l'État, on séparerait aujourd'hui la justice et l'économie. D'un côté, on ferait beaucoup de "social ", de l'autre, beaucoup d'argent. En quelque sorte, le pouvoir temporel appartiendrait aux entreprises et aux banques, et le pouvoir intemporel aux gouvernements. Les temples, les églises, les synagogues le céderaient aux grands ministères. »

Fabriquons et emballons en paix ! criaient-ils, vendons en liberté, et nous aurons en échange la paix et la liberté !

Une pareille grandeur d'âme ne laissait pas indifférents les peuples et les États. Entre tous, les États d'Amérique du Nord apparurent comme le peuple élu. Le monde changea de Judée. Jérusalem fut peu à peu remplacée par Washington. Quant à la politique, elle s'adapta à la religion nouvelle et forma ses prêtres. Que serait un dirigeant qui n'aurait ni lu ni compris les Tables de la nouvelle Loi ? Alors surgirent dans les Conseils des hommes d'un type nouveau, compétents, capables de gérer aussi bien une administration qu'une entreprise ou une grande compagnie. Le mot GESTION rompit un carcan multiséculaire, jeta bas ses oripeaux et apparut en cape d'or aux citoyennes et aux citoyens ébahis. Jadis, on cherchait à savoir d'un homme s'il était chrétien ou hérétique, à droite ou à gauche, communiste ou anglican. À l'époque dont je parle, on se demandait : celui-là est-il ou non un bon gestionnaire? 


\title{
2.13. La modulació de les repeticions
}

L'ús de la repetició i de l'anàfora (repetició d'una paraula al principi d'enunciats successius per emfasitzar el terme en qüestió) és més freqüent en uns idiomes que en d'altres. Les repeticions solen posseir un valor pragmàtic i estilístic que proporciona cohesió semàntica $\mathrm{i}$ cert efecte d'èmfasi. Però el text següent té també altres condicionants que cal descobrir.

(Text 13, 678 paraules)

\begin{abstract}
Supposons deux vaches
SOCIALISME : Vous avez deux vaches. Vos voisins vous aident à vous en occuper et vous vous partagez le lait.
\end{abstract}

COMMUNISME : Vous avez deux vaches. Le gouvernement vous prend les deux et vous fournit en lait.

FASCISME : Vous avez deux vaches. Le gouvernement vous prend les deux et vous vend le lait.

NAZISME : Vous avez deux vaches. Le gouvernement vous prend la vache blonde et abat la brune.

DICTATURE : Vous avez deux vaches. Les miliciens les confisquent et vous fusillent.

FÉODALISME : Vous avez deux vaches. Le seigneur s'arroge la moitié du lait.

DÉMOCRATIE : Vous avez deux vaches. Un vote décide à qui appartient le lait.

DÉMOCRATIE REPRÉSENTATIVE : Vous avez deux vaches. Une élection désigne celui qui décidera à qui appartient le lait.

DÉMOCRATIE DE SINGAPOUR : Vous avez deux vaches. Vous écopez d'une amende pour détention de bétail en appartement.

ANARCHIE : Vous avez deux vaches. Vous les laissez se traire en autogestion.

CAPITALISME : Vous avez deux vaches. Vous en vendez une, et vous achetez un taureau pour faire des petits.

CAPITALISME DE HONG KONG : Vous avez deux vaches. Vous en vendez trois à votre société cotée en bourse en utilisant des lettres de créance ouvertes par votre beau-frère auprès de votre banque. Puis vous faites un échange de dettes contre participation, assorti d'une offre publique, et vous récupérez quatre vaches dans l'opération tout en bénéficiant d'un abattement fiscal pour entretien de cinq vaches. Les droits sur le lait de six vaches sont alors transférés par un intermédiaire panaméen sur le compte d'une société des îles Caïman, détenue clandestinement par un actionnaire qui revend à votre société cotée les droits sur le lait de sept vaches. Au rapport de la dite société figurent huit ruminants, avec option d'achat sur une bête supplémentaire. Entre temps vous abattez les deux vaches par ce que leur horoscope est défavorable.

CAPITALISME SAUVAGE : Vous avez deux vaches. Vous équarrissez l'une, vous forcez l'autre à produire autant que quatre, et vous licenciez finalement l'ouvrier qui s'en occupait en l'accusant d'avoir laissé la vache mourir d'épuisement.

BUREAUCRATIE : Vous avez deux vaches. Le gouvernement publie des règles d'hygiène qui vous invitent à en abattre une. Après quoi vous fait déclarer la quantité de lait que vous avez pu traire de l'autre, il vous achète le lait et il le jette. Enfin il vous fait remplir des formulaires pour déclarer la vache manquante. 
ÉCOLOGIE : Vous avez deux vaches. Vous gardez le lait et le gouvernement vous achète la bouse.

FÉMINISME : Vous avez deux vaches. Le gouvernement vous inflige une amende pour discrimination. Vous échangez une de vos vaches pour un taureau que vous trayez aussi.

SURRÉALISME : Vous avez deux vaches. Le gouvernement exige que vous leur donniez des leçons d'harmonica.

CAPITALISME EUROPÉEN : On vous subventionne la première année pour acheter une 3 eme vache. On fixe des quotas la deuxième année et vous payez une amende pour surproduction. On vous donne une prime la $3 \mathrm{eme}$ année pour abattre la $3 \mathrm{eme}$ vache.

MONARCHIE CONSTITUTIONELLE BRITANNIQUE : Vous tuez une des vaches pour la donner à manger à l'autre. La vache vivante devient folle. L'Europe vous subventionne pour l'abattre. Vous la donnez à manger à vos deux moutons.

CAPITALISME À LA FRANÇAISE : Pour financer la retraite de vos deux vaches, le gouvernement décide de lever un nouvel impôt : la CSSANAB (cotisation sociale de solidarité avec nos amis les bêtes). Deux ans après, comme la France a récupéré une partie du cheptel britannique, le système est déficitaire. Pour financer le déficit on lève un nouvel impôt sur la production du lait : le RAB (Remboursement de l'Ardoise Bovine). Les vaches se mettent en grève. Il n'y a plus de lait. Les Français sont dans la rue : « DU LAIT, ON VEUT DU LAIT ». La France construit un lactoduc sous la Manche pour s'apprivoiser auprès des Anglais. L'Europe déclare le lait anglais impropre à la consommation. Le lactoduc ne servira jamais. On lève un nouvel impôt pour l'entretien du lactoduc.

\subsection{La precisió lèxica}

Un bon traductor no pot conformar-se amb l'equivalència més immediata que se li ocorre o amb la primera accepció del diccionari, sinó que la seua professionalitat l'obliga a seguir un itinerari exegètic cap a la màxima precisió, tot tenint en compte el camp o el tema del text original, però sense que això supose necessàriament una inversió excessiva en documentació.

\section{(Text 14, 729 paraules)}

Le contrat de travail à durée indéterminée (CDI) est la forme normale et générale de la relation de travail. Par définition, il ne prévoit pas la date à laquelle il prend fin. Il peut être rompu sur décision unilatérale soit de l'employeur (licenciement pour motif personnel ou pour motif économique, mise à la retraite), soit du salarié (démission, départ à la retraite), ou encore pour une cause extérieure aux parties (ex : cas de force majeure). Sa rupture peut aussi résulter d'un accord des deux parties élaboré dans le cadre du dispositif de « rupture conventionnelle » mis en place par la loi n²008-596 du 25 juin 2008.

S'il est conclu pour un temps plein, le CDI peut ne pas faire l'objet d'un écrit, sauf dispositions conventionnelles contraires.

Dans quels cas un CDI doit-il être conclu?

Le contrat de travail à durée indéterminée (CDI) constitue la forme normale et générale de la relation de travail. L'employeur doit donc avoir recours à ce type de contrat, sauf s'il peut justifier d'une situation autorisant le recours à un autre type de contrat, qu'il s'agisse notamment d'un contrat de travail à durée déterminée ou d'un contrat de travail temporaire. 
Le CDI peut être conclu pour un temps plein ou pour un temps partiel.

Quelle forme doit revêtir le CDI ?

Seul le contrat à durée indéterminée (CDI) à temps plein peut être non écrit (sauf disposition conventionnelle contraire imposant la rédaction d'un contrat écrit). Toutefois, si le contrat à durée indéterminée à temps plein reste verbal, l'employeur a l'obligation de remettre au salarié un document écrit reprenant les informations contenues dans la déclaration préalable à l'embauche adressée à l'URSSAF.

Le contrat de travail constaté par écrit doit être rédigé en français. Il peut toutefois arriver que l'emploi faisant l'objet du contrat ne puisse être désigné que par un terme étranger sans correspondant en français ; dans ce cas, le contrat de travail doit comporter une explication en français du terme étranger. Lorsque le salarié est étranger et le contrat constaté par écrit, une traduction du contrat est rédigée, à la demande du salarié, dans la langue de ce dernier. Les deux textes font également foi en justice. En cas de discordance entre les deux textes, seul le texte rédigé dans la langue du salarié étranger peut être invoqué contre ce dernier.

Quel est le contenu du CDI?

Il appartient à l'employeur et au salarié de déterminer le contenu du contrat de travail et les clauses particulières qui devront éventuellement y figurer en fonction des circonstances (clause de mobilité, clause de non-concurrence...), sachant toutefois :

- que les clauses contraires à l'ordre public sont interdites : clause de célibat, rémunération inférieure au Smic, clause discriminatoire...;

- que les contrats dont la rédaction est obligatoire doivent comporter, au minimum, les mentions prévues par le code du travail. Sont visés les contrats à durée déterminée ou de travail temporaire, mais aussi, s'agissant des CDI, ceux conclus pour un temps partiel ou encore les CDI intermittents.

Comment le CDI peut-il prendre fin ?

Le CDI se caractérise par l'absence de terme défini. Il ne peut donc prendre fin que par la volonté d'une des parties (licenciement, démission, mise à la retraite, départ volontaire à la retraite), par accord entre les parties (notamment dans le cadre du dispositif de « rupture conventionnelle » mis en place par la loi du 25 juin 2008) ou pour force majeure. Il peut également, dans des conditions très précises, faire l'objet d'une demande de résiliation judiciaire par le salarié, lorsque ce dernier considère que l'employeur a manqué à ses obligations (cette demande doit être portée devant le conseil des prud'hommes) ou d'une prise d'acte de la rupture. Dans ce dernier cas, le salarié, considérant que l'employeur a manqué à ses obligations, prend acte de la rupture du contrat et en informe par écrit son employeur : cette rupture produira alors les effets soit d'un licenciement sans cause réelle et sérieuse si les faits invoqués (le manquement de l'employeur à ses obligations) la justifiaient, soit, dans le cas contraire, d'une démission, cette appréciation relevant du conseil des prud'hommes.

Est considéré comme cas de force majeure, permettant à l'employeur de s'exonérer de tout ou partie des obligations nées de la rupture d'un contrat de travail, la survenance d'un évènement extérieur irrésistible ayant pour effet de rendre impossible la poursuite dudit contrat. 


\subsection{La denotació i la connotació}

Independentment del gènere, els textos posseeixen unes marques d'estil que s'han de tenir en compte, tant les que mostra la forma com les que pertanyen al fons. Si bé en la primera fase de la comprensió es dilucida el sentit a partir dels valors denotatius, cal sempre una segona etapa en què s'han d'analitzar els valors suplementaris, que són els connotatius.

(Text 15, 743 paraules)

\section{Le don des langues}

Certains peuples sont réputés « doués pour les langues »; les Slaves par exemple. Les Français, par contre, sont généralement considérés - par eux-mêmes - comme «peu doués ». Ce type de jugement rejoint le vaste catalogue des stéréotypes nationaux ou raciaux : les Noirs sont paresseux, les Écossais sont avares, les Français sont indisciplinés, les Anglais sont flegmatiques, etc. On tombe dès lors dans le piège de la " psychologie des peuples », qui était encore tout à fait crédible au début de ce siècle, mais que les scientifiques, sinon l'opinion publique, ont aujourd'hui dépassée.

La génétique moderne remet en cause l'existence des « dons », ces dons que les mythologies populaires attribuent aux « bonnes fées » penchées sur le berceau du nouveau-né. Selon Albert Jacquard, « chaque population est définie par l'ensemble des fréquences des différentes catégories de gènes observées ${ }^{1}$ ». Or, ce n'est pas le cas. Le « don » des langues, comme toutes les capacités intellectuelles, est le résultat de l'interaction d'un patrimoine génétique complexe et de l'environnement. Il se manifeste dans la mesure où il est encouragé par l'entourage ou favorisé par des circonstances socioculturelles particulières. Les brassages de population faussent de toute façon la donne génétique. Ainsi, par exemple, aux ÉtatsUnis, le fameux « creuset » mêle des populations de toutes origines, d'Europe, d'Afrique et d'Asie. Les cartes sont tellement brouillées que la faible aptitude de l'Américain moyen à l'apprentissage des langues étrangères doit s'expliquer essentiellement par des traits culturels et par des circonstances économiques et politiques.

Plus que de don des langues, il faut parler de réussite dans l'apprentissage des langues. Le bilinguisme précoce en est un facteur clé. Chacun sait que, plus on parle de langues, plus on éprouve de facilité à en apprendre d'autres, qu'elles soient apparentées ou non. Or, le multilinguisme est, dans nombre de pays, un trait de société plutôt qu'une caractéristique de l'individu. Prenons le cas d'un écolier dakarois d'origine casamançaise. Il y a de fortes chances pour que sa première langue soit le mandingue, le diola ou les deux. La langue parlée par la quasi-totalité de la population à Dakar est le wolof. À l'école, tous les cours sont dispensés en français. Trois ou quatre langues sont ainsi acquises dans la petite enfance et parlées quotidiennement. C'est une situation extrêmement banale en Afrique.

Certes, chacune des langues se répartit sur un terrain socioculturel différent : la maison, la rue, l'école ; chacune correspond à un registre, à un usage social déterminé, mais le fait polyglotte demeure. Voici réunies toutes les conditions pour un don des langues assignable à un peuple. Le fait que les préjugés européocentristes n'attribuent pas généralement cette caractéristique aux Africains ne fait que refléter le mépris dans lequel on a longtemps tenu les langues et les populations prétendument primitives.

Autrefois, plus un peuple était petit, plus il avait de chances d'être homogène et donc unilingue. Aujourd'hui, avec l'avènement des grandes entités nationales et des relations internationales, c'est l'inverse qui est vrai. Plus un groupe humain est faible numériquement, plus il est soumis aux influences et aux pressions des groupes plus puissants. En conséquence, ses membres sont contraints de se faire polyglottes et doivent donc être considérés comme « doués pour les langues ». La situation est aisément vérifiée en Europe, si l'on oppose, par exemple, les Danois ou les Hollandais, réputés bilingues, aux Anglais, indécrottables unilingues. 
Une autre explication est cependant disponible. Les diverses langues parlées dans le monde utilisent des fréquences acoustiques différentes. Outre le conditionnement articulatoire qui s'acquiert entre deux et quatre ans, il existe un conditionnement auditif par la langue maternelle. Ainsi un locuteur francophone a-t-il, au sens propre, du mal à entendre les langues qui utilisent des fréquences plus basses ou plus hautes. Les locuteurs de langues comme le russe seraient alors favorisés par une bande de fréquence très large (beaucoup plus large que celle $\mathrm{du}$ français), englobant celle de nombreuses autres langues. Naturellement, l'apprentissage d'une langue n'est pas seulement une question d'oreille, mais c'est un facteur important, notamment pour percevoir les sons distinctifs absents de la langue maternelle. Ceci expliquerait de façon satisfaisante le fait que les Russes ont effectivement des facilités pour les langues étrangères alors même qu'ils parlent une dominante. Et, inversement, le fait que les Français, contraints d'apprendre l'anglais, dont la bande de fréquence est plus élevée, n'y parviennent que médiocrement.

1. Cinq Milliards d'Hommes dans un vaisseau, Paris, Éd. du Seuil, 1987. 


\section{Capítol III. \\ Bibliografia bàsica i fonts de materials}

\subsection{Bibliografia sobre teoria de la traducció}

Burdeus, M. D. (1997): «Traducción y diversidad. Estado de la cuestión», dins Burdeus, M. D. i altres (eds.): La diversitat discursiva, Castelló, Publicacions de la Universitat Jaume I, 265-272.

Chuquet, H. i M. Paillard (1987): Approche linguistique des problèmes de traduction, París, Ophrys.

Ducrot, O. (1983): «Opérateurs argumentatifs et visée argumentative», Cahiers de linguistique, 5, 7-36.

Hurtado Albir, A. (2001): Traducción y traductología. Introducción a la traductología, Madrid, Cátedra.

Lvóvskaya, Z. (1997): Problemas actuales de la traducción, Granada, Impredisur.

Nord, CH. (1991): Text analysis in Translation, Amsterdam-Atlanta, Rodopi.

SAntoyo, J. C. (1994): «Traducción de cultura, traducción de civilización», dins Hurtado Albir, A. (ed.): Estudis sobre la traducció, Castelló, Publicacions de la Universitat Jaume I, 141-152.

VÁzQuez Ayora, G. (1977): Introducción a la traductología: curso básico de traducción, Washington, Georgetown University Press.

VégLiA, A. (1989): Manuel pratique de traduction, Madrid, Alhambra.

Verdegal, J. (2003): «La traducción de neologismos», Puntoycoma, 83, setembreoctubre, $7-20$.

\subsection{Bibliografia sobre didàctica de la traducció}

BeRTHELOt, M. (2007): Guide pratique de traduction catalan-français, Canet, Trabucaire.

Delisle, J. (1980): L'analyse du discours comme méthode de traduction, Ottawa, Éditions de l'Université d'Ottawa.

- (1998): «Définition, rédaction et utilité des objectifs d'apprentissage en enseignement de la traduction», dins Verdegal, J. i I. García IzQuierdo (eds.): Los estudios de traducción: un reto didáctico, Castelló, Publicacions de la Universitat Jaume I, 13-43.

Delisle, J. i H. Lee-JahnKe (dirs.) (1998): Enseignement de la traduction et traduction dans l'enseignement, Ottawa, Les Presses de l'Université d'Ottawa.

ELENA, P. (1996): «La documentación en la traducción general», dins HuRTADO Albir, A. (ed): La enseñanza de la traducción, Castelló, Publicacions de la Universitat Jaume I, 79-90.

Hernández Guerrero, M. J. (1995): «Aspectos de didáctica de la traducción», dins Martín-Gaitero, R. (ed.): V Encuentros Complutenses en torno a la traducción, Madrid, Universidad Complutense, 105-113. 
Hurtado Albir, A. (dir.) (1999): Enseñar a traducir. Metodología en la formación de traductores e intérpretes, Madrid, Edelsa.

Larose, R. (ed.) (1989): L'erreur en traduction, Traduction - Terminologie Rédaction (TTR), 2.

SÁnchez TRIGO, E. (1998): «Traducción general francés-español: objetivo y desarrollo de las clases», dins GarcíA-SABell, T. i altres (eds.): Les chemins $d u$ texte, II, Santiago de Compostela, Servicio de Publicacións e Intercambio Científico de la Universidade de Santiago de Compostela, 454-469.

TricÁs Preckler, M. (1995): Manual de traducción francés/castellano, Barcelona, Gedisa.

VeRDEGAL, J. (2010): Me gusta traducir del francés: curso de traducción general, Oviedo, Septem Ediciones.

- (2011): La pràctica de la traducció francès-català, Vic, Eumo Editorial, Universitat Autònoma de Barcelona, Universitat Jaume I, Universitat Pompeu Fabra, Universitat de Vic.

\subsection{Altres bibliografies}

BARri i MASATS, M. (1999): Aportació a l'estudi dels gal-licismes del català, Barcelona, Institut d'Estudis Catalans.

Morales, A. (1985): «Entrenamiento en el uso de estrategias para comprender la lectura», La Educación, 98, 9.

Nicolas, D. (2006): «Ambiguïté», dins Godard, D. i altres (eds.): Sémanticlopédie: dictionnaire de sémantique, GDR Sémantique \& Modélisation, CNRS. $<\mathrm{http}$ ://www.semantique-gdr.net/dico/>.

Roffé Gómez, A. (1992): «Delimitación de los argots como variedades lingüísticas», dins GutiÉrRez DíEz, F. (ed.) (1992): El español, Lengua Internacional (1492-1992). I Congreso Internacional de AESLA, Múrcia, AESLA, 477-481.

WARTBURG, W. von (1966): Evolución y estructura de la lengua francesa, Madrid, Gredos.

WeInRICH, H. (1974): Estructura y función de los tiempos en el lenguaje, Madrid, Gredos.

\subsection{Diccionaris i obres de consulta}

Badia i Margarit, A. M. (1985): Gramática catalana, Madrid, Gredos.

Capó Frau, J. i M. Veiga Fernández (2005): Abreviacions, Barcelona, Generalitat de Catalunya. Departament de la Presidència. $<$ http://www20.gencat.cat/docs/ Llengcat/Documents/Publicacions/Altres/Arxius/abrevia.pdf $>$.

Cuxart, R. (1999): Diccionari Ideològic de la Llengua Catalana, Barcelona, Llibres de l'Índex.

Dulin, N. i S. PALAfox (2000): Repères grammaticaux fondamentaux en français, Madrid, UNED. 
Ginebra, J. i A. Montserrat (1999): Diccionari d'ús dels verbs catalans, Barcelona, Edicions 62.

Grevisse, M. (2007): Le bon usage, Gembloux, Duculot.

Guilbert, L. (1975): La créativité lexicale, París, Larousse.

Robert Électronique, Le (2000): Le Robert électronique, version Windows 1.4. (monoposte), París, Dictionnaires Le Robert.

Robert, P. (1985): Le Grand Robert de la langue française, París, Dictionnaires Le Robert.

\subsection{Fonts de materials}

Bertier de Sauvigny, G. de (1977): Histoire de France, París, Flammarion (contracoberta).

Buccianti, A. (2003): «Toute nue, la reine Néfertiti bouleverse l'Egypte», Le Monde, 10 juny. $<$ http://itinera.fltr.ucl.ac.be/actualites/nouvelles.cfm?num=133>.

Delafontaine, J. (2008): «Le concert très sexe de Sébastien Tellier», Le matin bleu, 198, 10 octubre, XIII.

LAw, PH. (2007): «Perte sèche à Zaventem», La Libre Belgique, 13 abril. <http:// www.lalibre.be/actu/belgique/article/342653/perte-seche-a-zaventem.html>.

Pilhes, R.-V. (1974): L'imprécateur, París, Seuil, 13-15.

SAGEt, E. (2005): «Moi, rat de labo accro au tabac», L'Express, 12 setembre. $<$ http:// forum.doctissimo.fr/sante/arreter-fumer/labo-accro-tabac-sujet_159104_1.htm>.

VIDON, I. (2008): «Tout frais, tout près», Migros Magazine 41, 6 octubre, 69. $<\mathrm{http}$ ://www.fermegonin.com/images-presse/Presse.pdf $>$.

Yaguello, M. (1998): Catalogue des idées reçues sur la langue, París, Seuil. $<\mathrm{http}: / / \mathrm{www}$. google.es/search?hl=ca\&client=firefox-a\&hs $=\mathrm{x} 8 \mathrm{P} \& \mathrm{rls}=$ org.moz illa $\% 3 \mathrm{Aca} \% 3$ Aofficial\&channel $=\mathrm{s} \& \mathrm{q}=\% 22 \mathrm{Certains}+$ peuples + sont $+\mathrm{r} \% \mathrm{C} 3 \% \mathrm{~A}$ 9 put $\% \mathrm{C} 3 \% \mathrm{~A} 9 \mathrm{~s}+\% \mathrm{C} 2 \% \mathrm{AB}+$ dou $\% \mathrm{C} 3 \% \mathrm{~A} 9 \mathrm{~s}+$ pour + les + langues $+\% \mathrm{C} 2 \% \mathrm{BB} \% 2$ $2 \& b \operatorname{tnG}=$ Cerca\&aq $=$ f\&aqi $=\& a q l=\& o q=\& g s \_r f a i=>$.

\subsection{Pàgines web}

http://fr.wikipedia.org/wiki/Vous_avez_deux_vaches.

http://www.hc-sc.gc.ca/hl-vs/iyh-vsv/life-vie/drink-boire-fra.php.

http://www.minefe.gouv.fr/directions_services/dgefp/contrats/vue_ensemble/pratique/contrat_travail_duree_indeterminee.php.

http://www1.france-jeunes.net/lire-phenomene-book-crossing-12085.htm. 